\title{
Review
}

\section{Floating PVs in Terms of Power Generation, Environmental Aspects, Market Potential, and Challenges}

\author{
Erdem Cuce ${ }^{1,2, *(\mathbb{D}}$, Pinar Mert Cuce ${ }^{1,3}$, Shaik Saboor ${ }^{4}\left(\mathbb{D}\right.$, Aritra Ghosh ${ }^{5,6}\left(\mathbb{D}\right.$ and Yahya Sheikhnejad ${ }^{7,8} \mathbb{D}$
}

Citation: Cuce, E.; Cuce, P.M.; Saboor S.; Ghosh, A.; Sheikhnejad, Y. Floating PVs in Terms of Power Generation, Environmental Aspects, Market Potential, and Challenges. Sustainability 2022, 14, 2626. https:// doi.org/10.3390/su14052626

Academic Editor: Luis M.

Fernández-Ramírez

Received: 20 January 2022

Accepted: 18 February 2022

Published: 24 February 2022

Publisher's Note: MDPI stays neutral with regard to jurisdictional claims in published maps and institutional affiliations.

Copyright: (C) 2022 by the authors. Licensee MDPI, Basel, Switzerland. This article is an open access article distributed under the terms and conditions of the Creative Commons Attribution (CC BY) license (https:// creativecommons.org/licenses/by/ $4.0 /)$.
1 Low/Zero Carbon Energy Technologies Laboratory, Faculty of Engineering and Architecture, Zihni Derin Campus, Recep Tayyip Erdogan University, Rize 53100, Turkey; pinar.mertcuce@erdogan.edu.tr

2 Department of Mechanical Engineering, Faculty of Engineering and Architecture, Zihni Derin Campus, Recep Tayyip Erdogan University, Rize 53100, Turkey

3 Department of Architecture, Faculty of Engineering and Architecture, Zihni Derin Campus, Recep Tayyip Erdogan University, Rize 53100, Turkey

4 School of Mechanical Engineering, Vellore Institute of Technology (VIT), Vellore 632014, Tamil Nadu, India; saboor.nitk@gmail.com

5 College of Engineering, Mathematics and Physical Sciences, Renewable Energy, University of Exeter, Penryn TR10 9FE, Cornwall, UK; a.ghosh@exeter.ac.uk

6 Environmental and Sustainability Institute, University of Exeter, Penryn TR10 9FE, Cornwall, UK

7 PICadvanced SA, Creative Science Park, Via do Conhecimento, Ed. Central, 3830-352 Ílhavo, Portugal; yahya.sheikhnejad@picadvanced.com

8 Centre for Mechanical Technology and Automation, Department of Mechanical Engineering, Universidade de Aveiro, 3810-193 Aveiro, Portugal

* Correspondence: erdem.cuce@erdogan.edu.tr

\begin{abstract}
Limited reserves of fossil fuels, rising environmental concerns, and a remarkable increase in electricity demand have led to the necessity of harnessing solar energy on a large scale. For this purpose, there has been a noticeable stimulation into photovoltaic power plants (PVPPs) over the last three decades, but the land requirement for PVPPs is still a handicap in many countries since valuable lands are considered for other purposes such as agriculture and livestock. For effective conservation of valuable lands and water resources, PVPPs are preferred to be installed on various water bodies such as oceans, seas, lagoons, lakes, rivers, dams, canals, wastewater treatment plants, irrigation ponds, fish farms, wineries, reservoirs, etc. PV systems on water bodies are called floating PVPPs, and they have outstanding advantages compared with land-based PVPPs including better energy generation owing to passive cooling effects, higher system efficiency and reliability, and lower dirt and dust accumulation on PV modules thus lower operating costs. There are also some significant environmental features provided by floating PVs. Shading effects due to PV coverage reduce water losses arising from evaporation. Moreover, algae growth is limited because of mitigated solar radiation, which yields better water quality. This review presents more insight on floating PVPPs in terms of several aspects such as electricity generation, system efficiency, reliability and sustainability, experimental applications and facilities in operation, water and carbon saving as well as challenges.
\end{abstract}

Keywords: solar PV; floating PV power plants; electricity generation; system efficiency; water saving

\section{Introduction}

In the 21st century, one of the most crucial issues is eco-friendly energy supply. There is no doubt that renewable energy sources (RES) play a notable role in cost-effective, sustainable, and environmentally desirable energy production on a global scale. As declared by the International Energy Agency (IEA) [1], nearly 14\% of the total primary energy supply (TPES) is fulfilled by RES composed of hydro, biofuels and waste, solar, wind, geothermal, and tidal, according to the data of 2017. The annual increase in renewable energy supply is $2 \%$ between 1990-2017. However, the growth rate of TPES is at the level of $1.7 \%$ annually. 
It is demonstrated in Figure 1 that solar PVs account for $37 \%$ of the annual growth rate of the energy supply. Wind power has the second-highest growth rate at $24 \%$, followed by biogases, solar thermal, and liquid biofuels, etc.

40

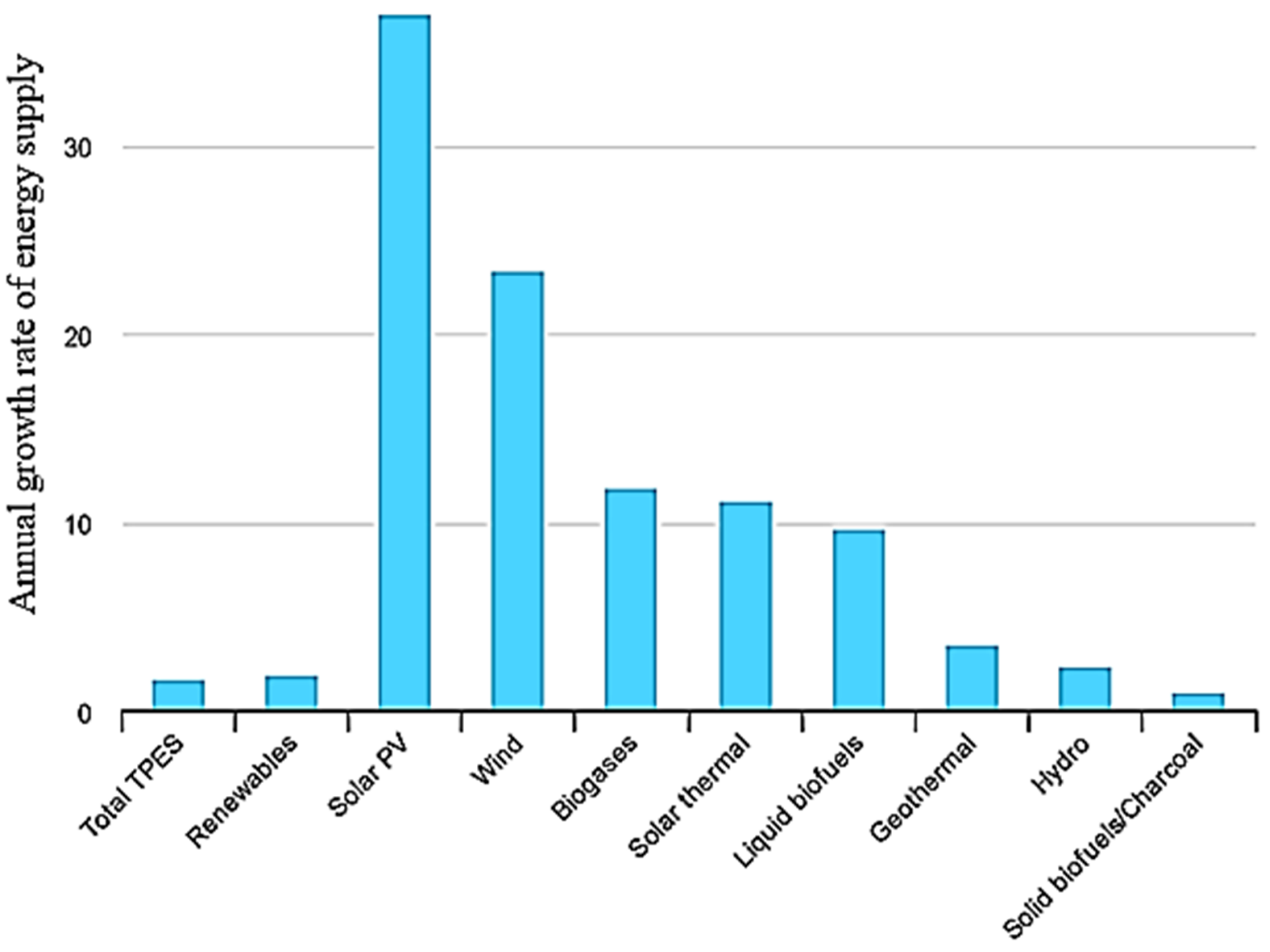

Figure 1. Average annual growth rates of RES supply between 1990 and 2017 [1].

Among the RES, the advancements in solar PVs are exceptional especially over the last two decades as shown in Figure 2. An exponential increase is observed in solar-PV-based electricity generation. When the electricity generated in 2016 and 2017 is evaluated, an outstanding rise of about 115TWh is noticed in solar PV electricity [2]. The ongoing interest in solar PV technology can be ascribed to a couple of reasons as follows:

- Simplicity and reliability

- Scalability

- Low costs

- Availability worldwide

- Limited environmental impacts

Despite the aforesaid superiorities, there are two main challenges for solar PV technology which considerably limit these systems to become widespread. The first handicap is "land use" as about $15,000 \mathrm{~m}^{2}$ of land is necessary to install a $1 \mathrm{MW}$ solar PV plant. The second challenge is "low incentives" since the PV market suffers from not being able to compete with the other RES because of the low incentive rates [3]. In this respect, alternative solutions are considered for solar PVs to be able to overcome the said drawback in practice. Floating PVs (FPVs) is such a solution that can be considered as a new concept of harnessing solar energy. FPVs have more competitive advantages in countries with scarce or expensive land for installing land-based photovoltaics (LBPVs). To be able to consider 
FPV systems as an alternative to land-based PVs, abundant and convenient water resources are required to be available in the region for the installation of FPVs. It is emphasized in the literature that water losses in any resource due to evaporation occurring from water surfaces can be considerably decreased through using FPV. Not only that, but the energy performance of FPV is reported to be quite higher compared with LBPVs. Therefore, this research aims at pointing out the pros and cons of deploying FPV systems to water bodies in terms of energy generation potential and environmental aspects. From this point of view, comprehensive comparisons between FPV and LBPV are done within the scope of several performance parameters such as energy production, carbon and water saving, and the quality of water basins when covered with FPVs.

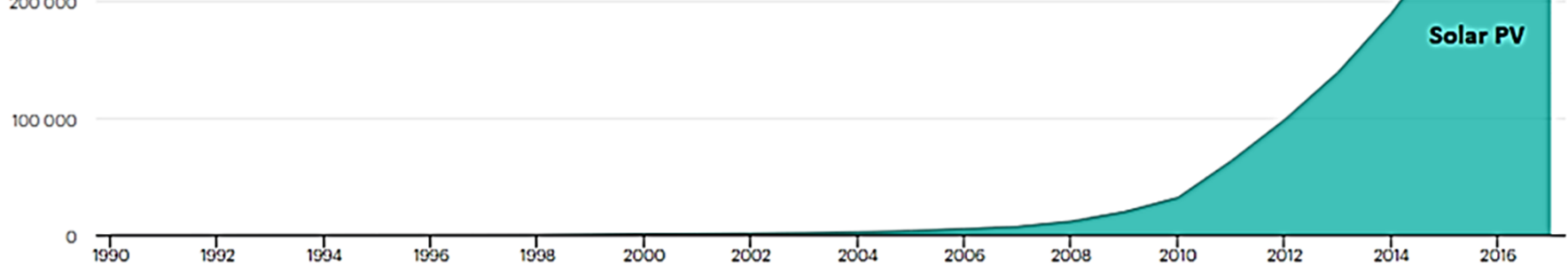

Figure 2. Total world renewable electricity generation by solar PV systems between 1990 and 2017 [2].

\section{Solar PV Systems}

Solar electricity based on PVs has an expanding range of applications especially over the last two decades. In this regard, it is useful to classify the installations of PV systems as the goal of this section. Solar PV applications can be split into five commonly known groups as depicted in Figure 3 [4].

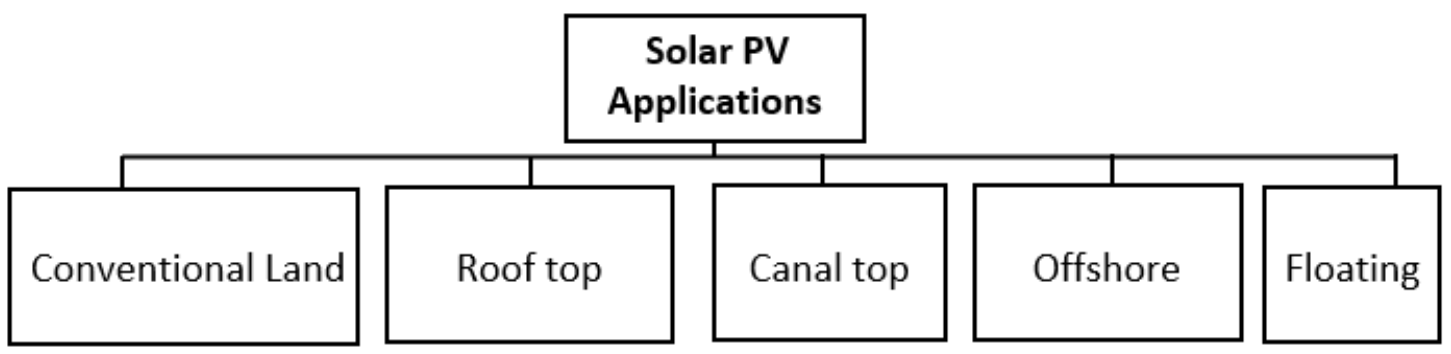

Figure 3. Types of solar PV installations [4].

\subsection{Conventional Land-Based Solar PV Applications}

Installation of PV systems on lands for small, middle, and large scale electricity generation purposes is the most common understanding of solar PV applications. LBPVs can be basically described as mounting PV arrays on land at a certain DC power capacity to be able to achieve a target AC power. The solar modules of PV arrays are fixed in the ground by land-based mounting equipment such as pole mounts, foundation mounts, and ballasted footing elements. 


\subsection{Roof Top PV Applications}

PV systems can be integrated into residential or commercial buildings as a roof [5] or facade application $[6,7]$ to generate electricity. The electricity generated can be consumed both on-grid and off-grid. Roof-type PV systems are usually preferred in rural areas where access to the power grid is difficult or expensive [8]. The area covered by rooftop PV systems is quite small compared with ground-mounted PV applications. In addition, LBPVs show higher electricity generations in contrast to the rooftop, depending on the installed power capacity.

\subsection{Canal Top PV Applications}

Canal top PV systems are installed above the water canal not to occupy the large scale of land area as shown in Figure 4. These systems operate more efficiently than LBPVs due to the continuous cooling effects through the back surface of PV modules [9]. The air medium beneath the PV modules acts as a thermal insulator and prevents them from warming up by mitigating the thermal effects from the ground [10]. Canal top PV systems also contribute substantially to the use of the land areas efficiently [11].

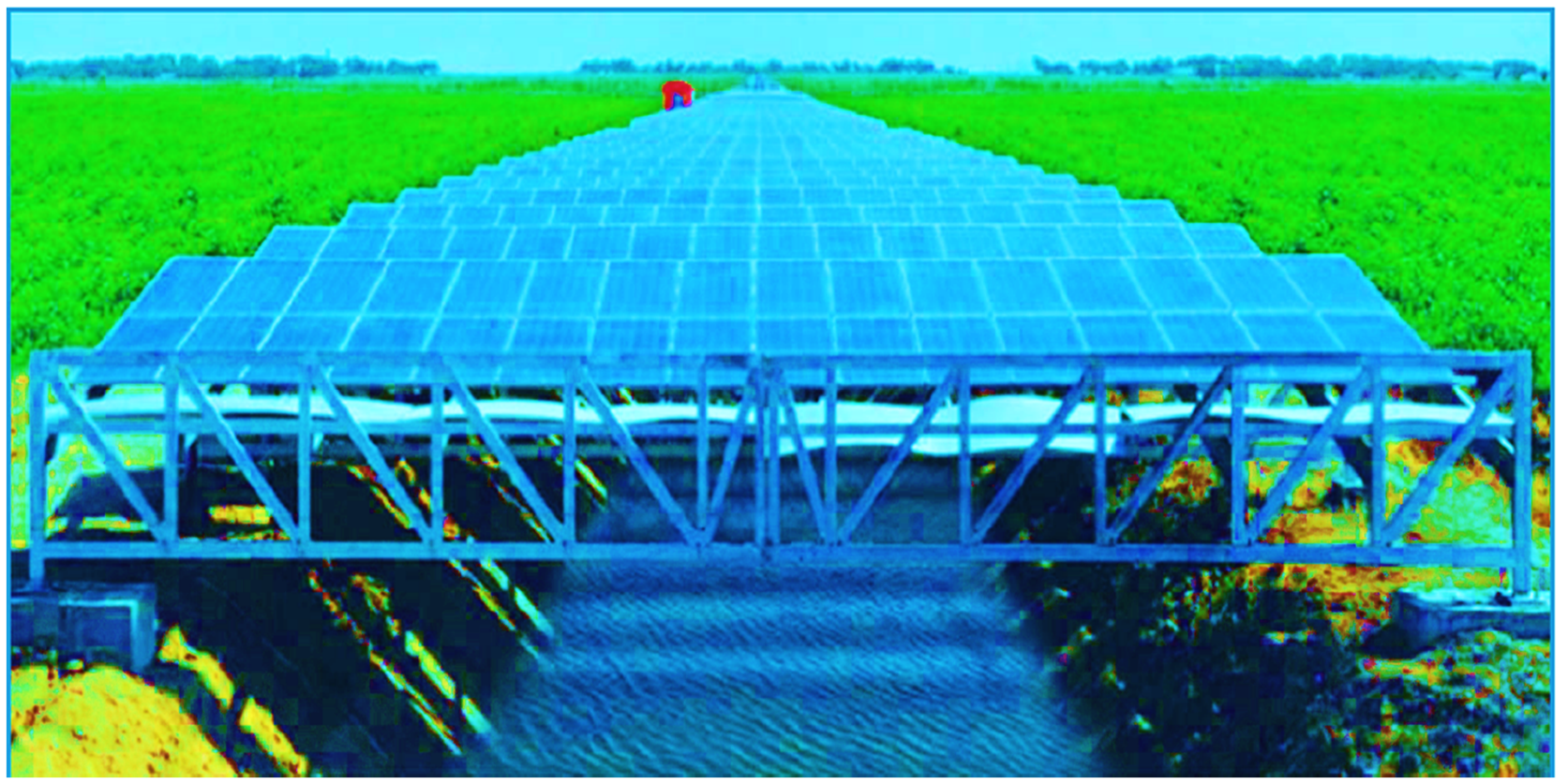

Figure 4. Canal-type solar PV installations [11].

\subsection{Offshore Solar PV Applications}

Oceans account for more than two-thirds of the world. Oceans and seas can be considered as potential energy sources owing to receiving huge amounts of solar radiation. For this reason, these water resources are used to generate electricity by utilizing offshore solar PV technologies [12]. By the means of these applications, agricultural land is not required to be destroyed unless compulsory.

\subsection{Floating PV Applications}

Among the solar PV applications, floating systems draw attention year after year as a consequence of remarkably better energy generation performance and outstanding environmental effects. A typical FPV system can be defined as the solar PV arrays installed on the water basin surfaces such as hydropower plants, freshwater, and human-made reservoirs, mining ponds, water treatment facilities, near the coast of seas or oceans as illustrated in Figure 5 [13]. FPV systems can be designed in different ways for different purposes. However, the main system components are almost the same as follows: PV 
modules, inverter, floats or pontoons, mooring systems, and cables [14,15]. The components of FPV are clearly demonstrated in Figure 6.
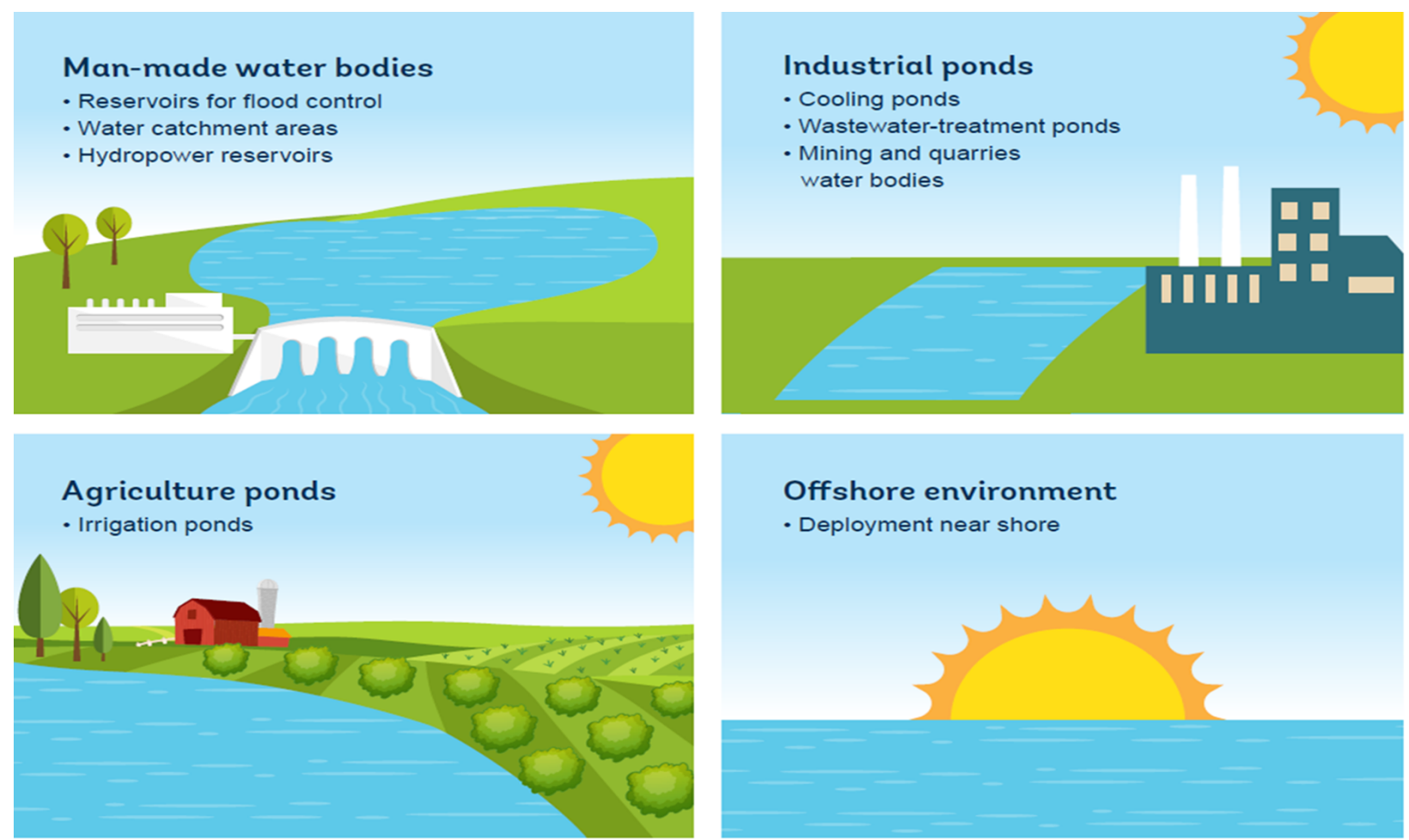

Figure 5. Schematic illustrations of FPV applications [13].

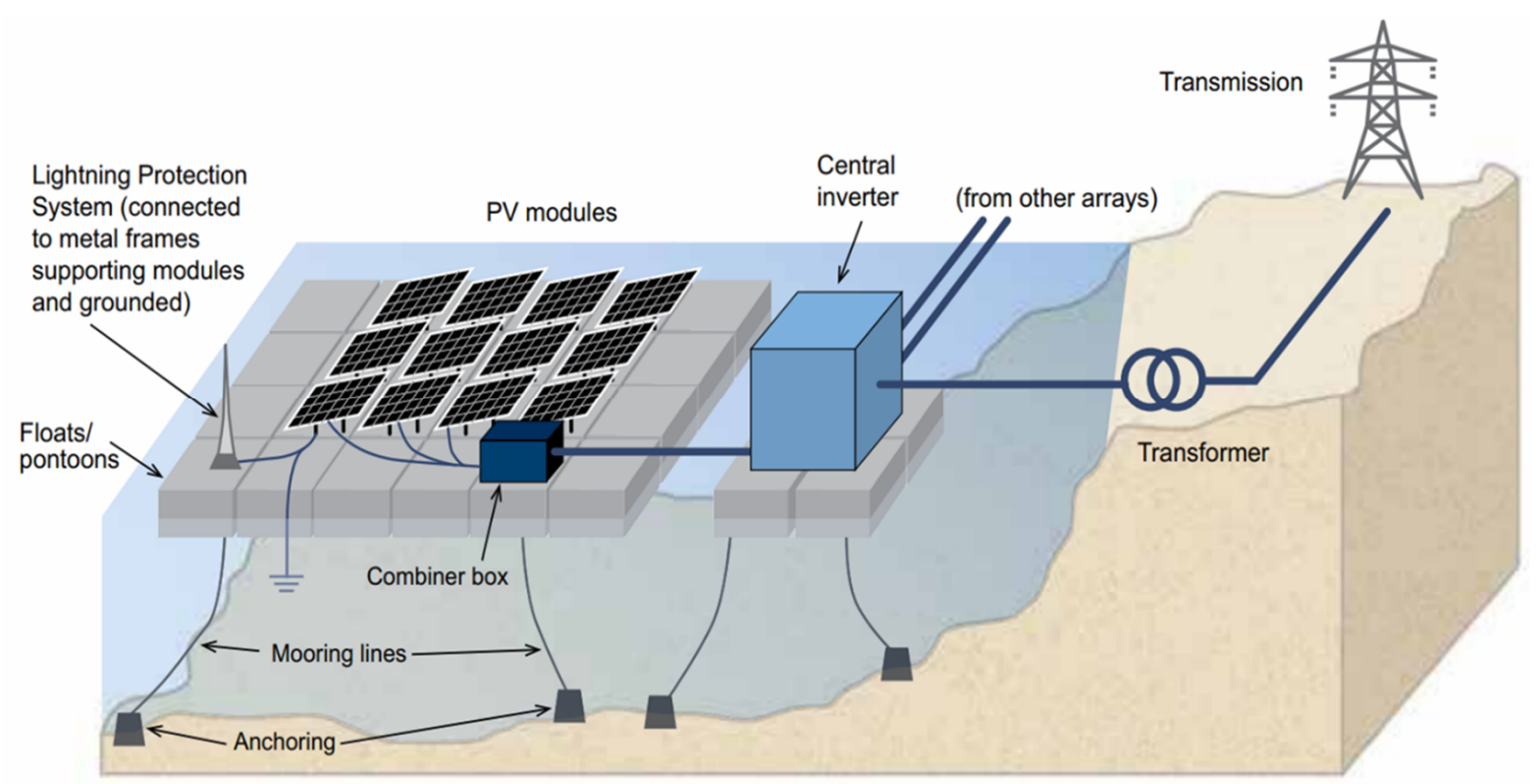

Figure 6. Main system components of FPV applications [13]. 
The first FPV system was installed in Japan in 2007 for scientific purposes. Afterward, FPV systems were considered to be built for commercial purposes, and the first applications were observed in the USA by utilizing the water reservoir [16]. The installed capacity of the first FPV system in the USA was reported to be $175 \mathrm{~kW}$. The recent reports of the World Bank indicate that there is a clear stimulation of the installation of FPV systems around the globe, notably, by Far East countries (Japan, Republic of Korea, and China), the USA, the U.K., Netherlands, Norway, Portugal, Spain, Singapore, Turkey, and Vietnam. The growth in FPV installation is illustrated in Figure 7 by using two different parameters such as cumulative and annual installed capacity (reached up to $1.3 \mathrm{GW}$ and $786 \mathrm{MW}$, respectively) [17].

When the installed capacities of FPV systems are investigated at the country level as shown in Figure 8, it is understood that China accounts for about 73\% of the total installed FPV systems worldwide [17]. China is followed by the Republic of Korea, Taiwan, and the U.K. It is explained in different works that the increase in the installed FPV systems depends on several advantages of the FPVs compared with other PV systems. The aforesaid superiorities of FPVs compared with LBPVs are useful to discuss as follows for easier understanding of the scope and findings [18,19]:

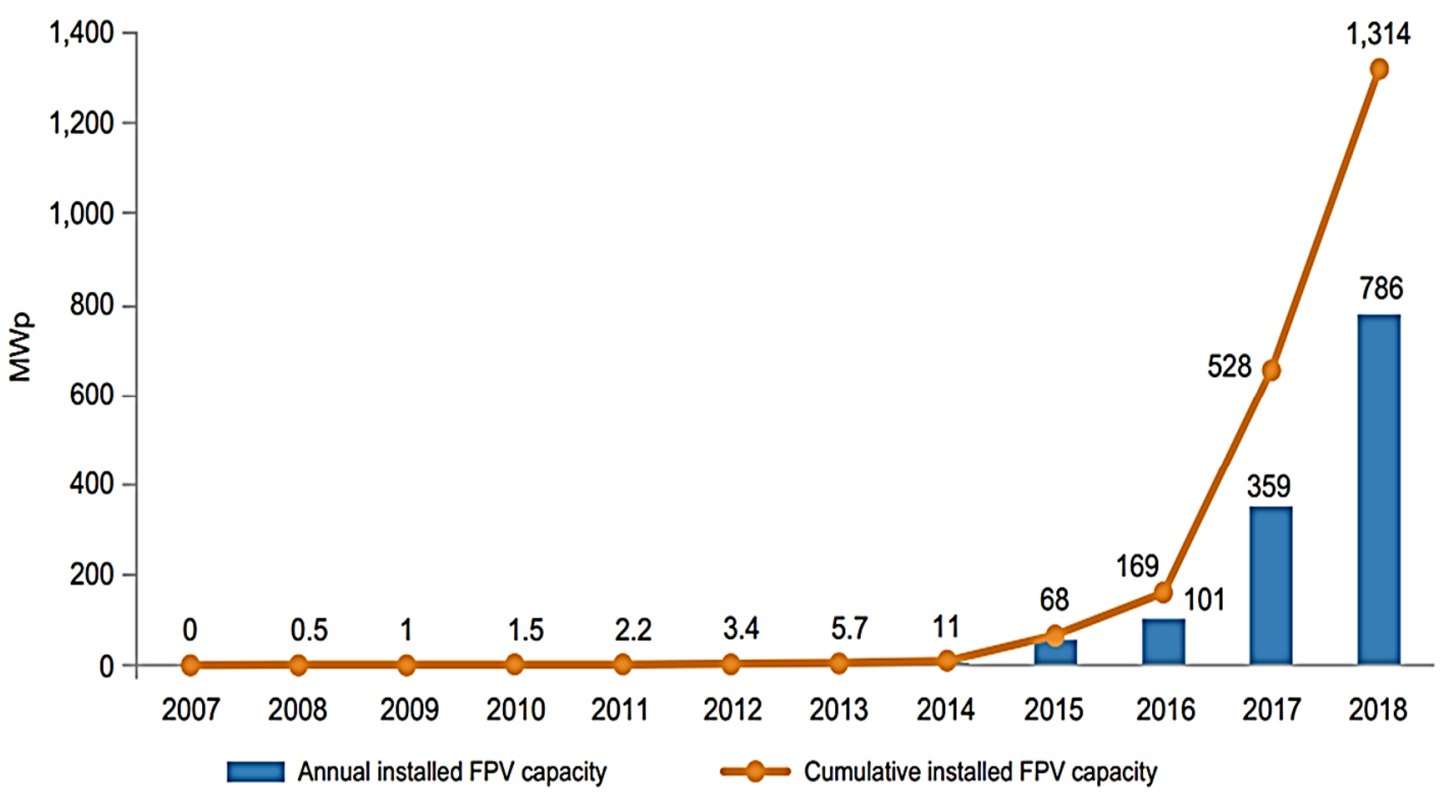

Figure 7. Installed capacity of FPV systems at a global scale [17].

\subsubsection{The Increase in Land Saving}

One of the major handicaps of LBPVs is the massive land occupation requirement of the power plant, and FPVs are at the center of interest to overcome this challenge. It is unequivocal that there are no negative impacts of FPVs on farmland and any other land relating to industrial or residential usage. FPVs also do not cause any problem regarding the landscape. The land saving feature of FPVs is of vital importance, and as an example from a pilot plant in Japan, a 13.7 MW FPV system installed on the Yakamura Dam water surface provides an approximate land saving of $43,000 \mathrm{~m}^{2}$, which is notable. The aforesaid power plant is illustrated in Figure 9 [20]. 

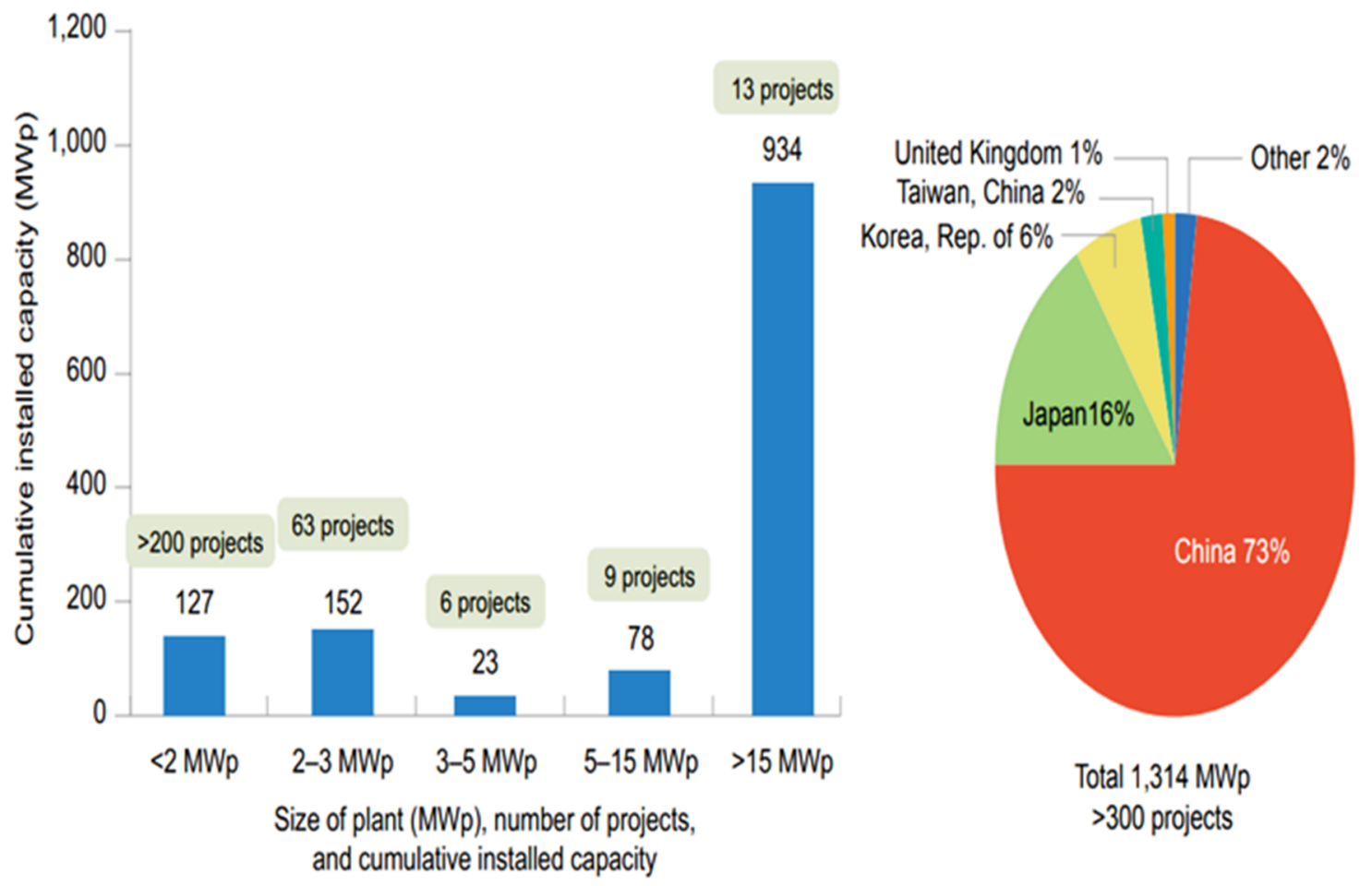

Figure 8. The worldwide distribution of installed FPV plants by 2018 [17].

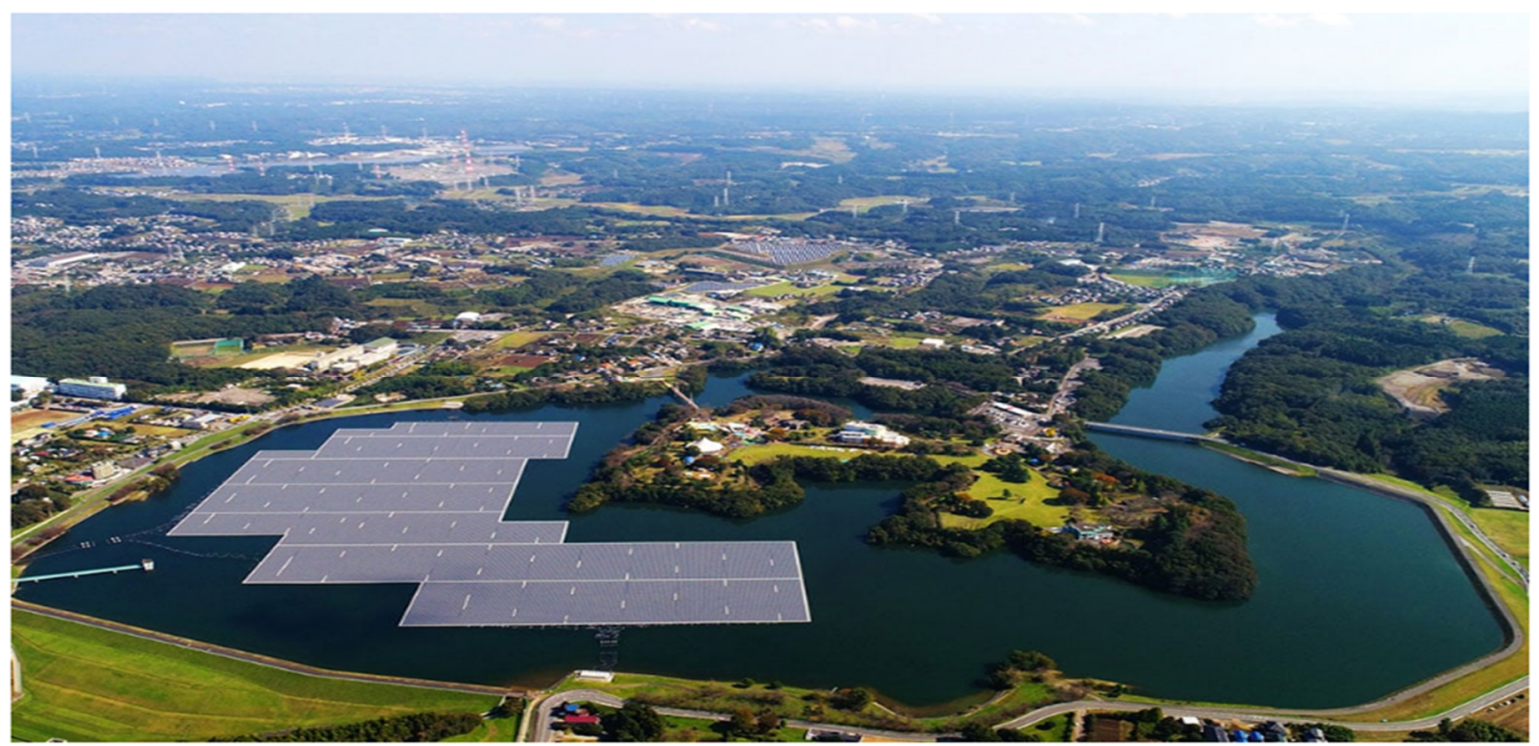

Figure 9. Land-saving by large-scale FPV installation covering the water surface in Japan [20].

\subsubsection{The Improvement in Energy Generation}

It is well documented in literature that PV module performance is highly dependent on environmental conditions [21]. In particular, greater operating temperatures cause remarkable reductions in efficiency terms and energy generation performance due to the dependency of voltage parameters on cell temperature [22]. In addition, dust, dirt, and shadow effects considerably deteriorate the electrical performance characteristics of PV systems due to their influence on main cell parameters [23]. FPV systems are observed to give better energy generation performance on site because of several reasons. Continuous evaporation effects from the water surface keep PV modules operating in a regulated 
temperature range. Dust accumulation is almost negligible on FPV systems, and it is very easy to clean the PV module surfaces when dirt occurs owing to the water source nearby.

\subsubsection{The Assembly and Dismantling of the System}

The installation is a costly process for LBPVs in most cases depending on locational prerequisites. When compared with LBPVs, not much effort is required to install and dismantle FPV systems. Unlike the fixed land-based solar plants with foundations, the structure can be simply mobilized anywhere due to the features of the mooring systems. Figure 10 shows the FPV installation steps on a water reservoir [17].
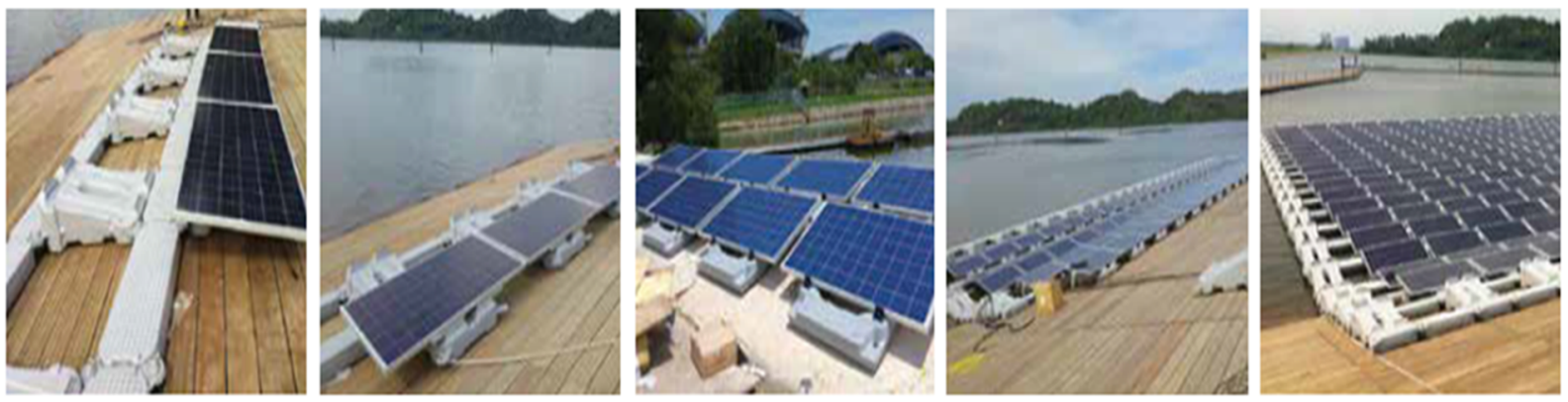

Figure 10. The construction process of FPV systems on a water source [17].

\subsubsection{Water Saving}

FPV systems are also preferred to LBPVs because of their positive influence on water saving. The findings from the practical applications reveal that a significant reduction in the evaporation on the water surface is observed when the water basins are covered by FPVs. From this point of view, especially in the regions with water scarcity, FPV systems are appropriate to consider on water sources for minimum water losses due to evaporation.

A comprehensive comparison of LBPV and FPV systems is presented in Table 1. The comparison is carried out critically over some key parameters including energy-yielding, investment, operation and maintenance, and so forth. Despite some minor challenges, it can be asserted that FPVs are ideal in most cases when energy generation performance and environmental issues are taken into consideration.

Table 1. A comprehensive comparison between FPV and LBPV systems [17].

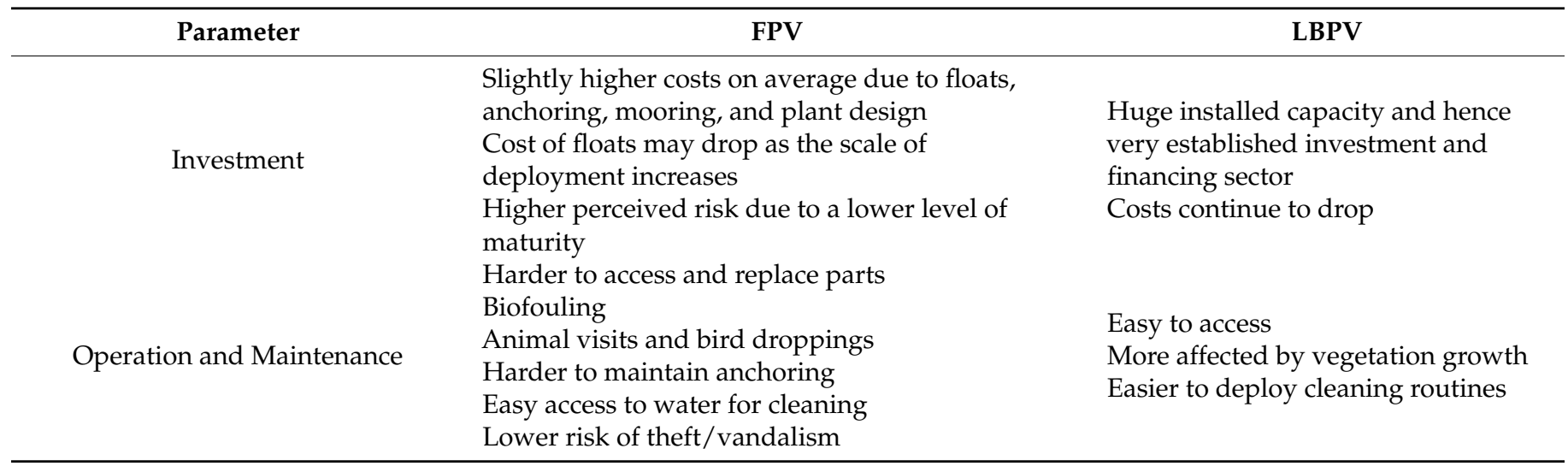


Table 1. Cont.

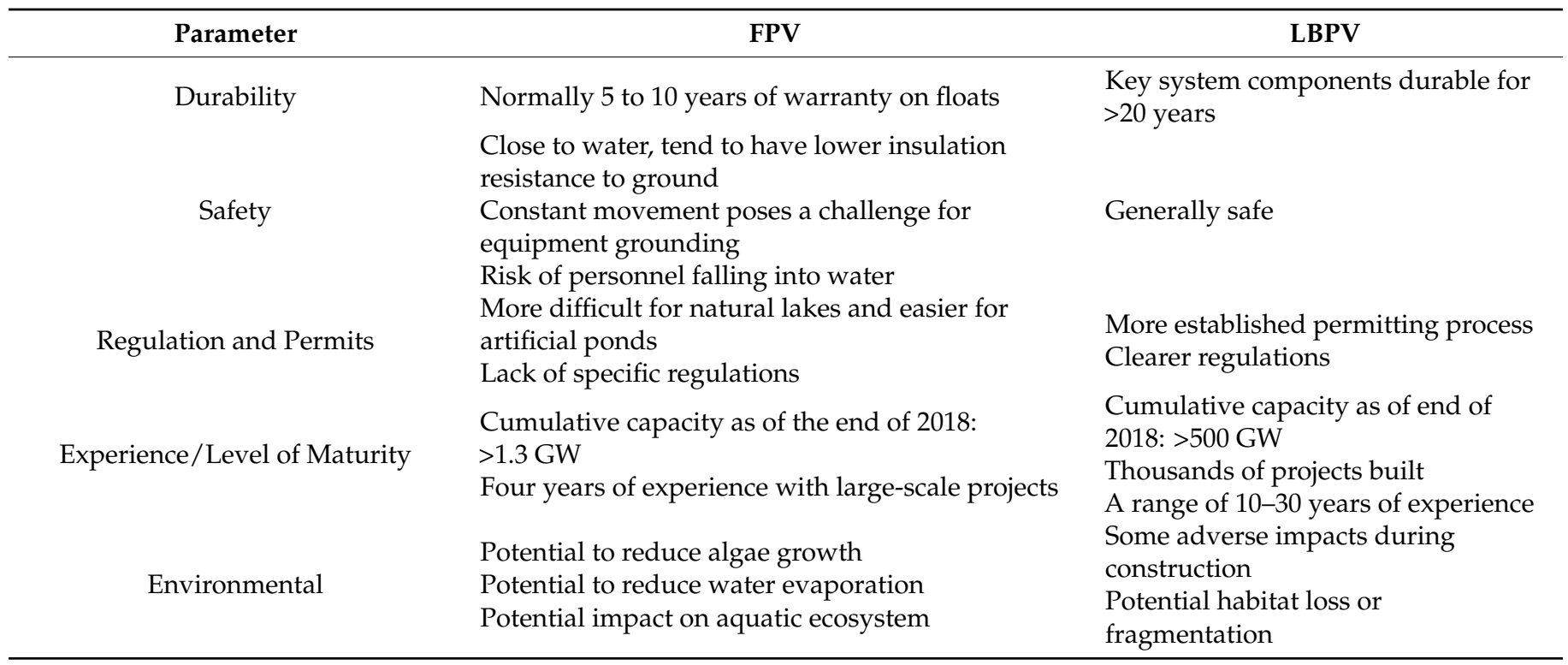

\section{The Contributions}

Following a review of recent literature in FPV systems, it is understood that numerous studies focus on revealing outstanding contributions of FPVs to efficient energy harnessing from the sun and effectively reducing the losses from water sources due to evaporation. Water saving and notably better energy generating performance are the key benefits of FPVs when compared with LBPV systems.

\subsection{Enhanced Energy Generation}

The panel temperature of PV modules affects the main performance parameters of PV systems such as efficiency and power generation, in particular [24]. The panel temperature is changeable on the basis of the material used as panel coverages, the heat removal properties of the materials, and weather conditions, namely, solar radiation, temperature, and wind [25-27]. Panel temperature can be decreased by using a water or air-based cooling system in practice [28-30]. In the case of FPVs, it is also possible to reduce the operating temperature of PV modules via evaporative cooling [31]. FPV power plants display higher efficiency compared with LBPV systems on account of evaporative cooling effects, fewer dust particles restricting the energy generations, and so on [32]. The performance of the PV modules is mitigated due to the coverage of some substances including soiling and biosoiling (leaves and bird droppings). The effects of biosoiling losses on FPV energy yields are reduced with the tilt angle fixed at $5-20^{\circ}$, but $10^{\circ}$ is reported as the recommended angle to provide self-cleaning via rainfall for cleaning the modules in FPV systems [17].

It is mentioned that evaporative cooling reduces the operational temperature of FPVs up to $3.5^{\circ} \mathrm{C}$ when compared with LBPVs [33]. According to the findings of experimental research carried out in Spain, an FPV system with a surface area of $4490 \mathrm{~m}^{2}$ installed on an irrigation water reservoir shown in Figure 11 is capable of generating $425 \mathrm{MWh}$ annual electrical energy [34]. In another study, it is addressed to install a $1 \mathrm{MW}$ FPV power plant at a limestone mine located in Korea. According to the simulation results, about $971.57 \mathrm{MWh}$ annual energy generation can be achieved with a $40^{\circ}$ tilt angle of PV modules [35]. Similarly, the study carried out by Kim et al. [36] focuses on the energy generation via FPV systems installed on 1134 water reservoirs in Korea by utilizing commercial software. The predicted energy generation from the FPV system covering $10 \%$ of water-basin areas is determined to be nearly $2932 \mathrm{GWh} /$ year. In a recent study, the potential energy generations from FPV installation at four different lakes covering $5 \%, 10 \%, 15 \%$, and $20 \%$ of the water basin is assessed by adopting a software program. The findings indicate that the energy generations 
are found to be in the range of 5189 and $54,606 \mathrm{MWh} /$ year depending on the lake and the rate of coverage [37].

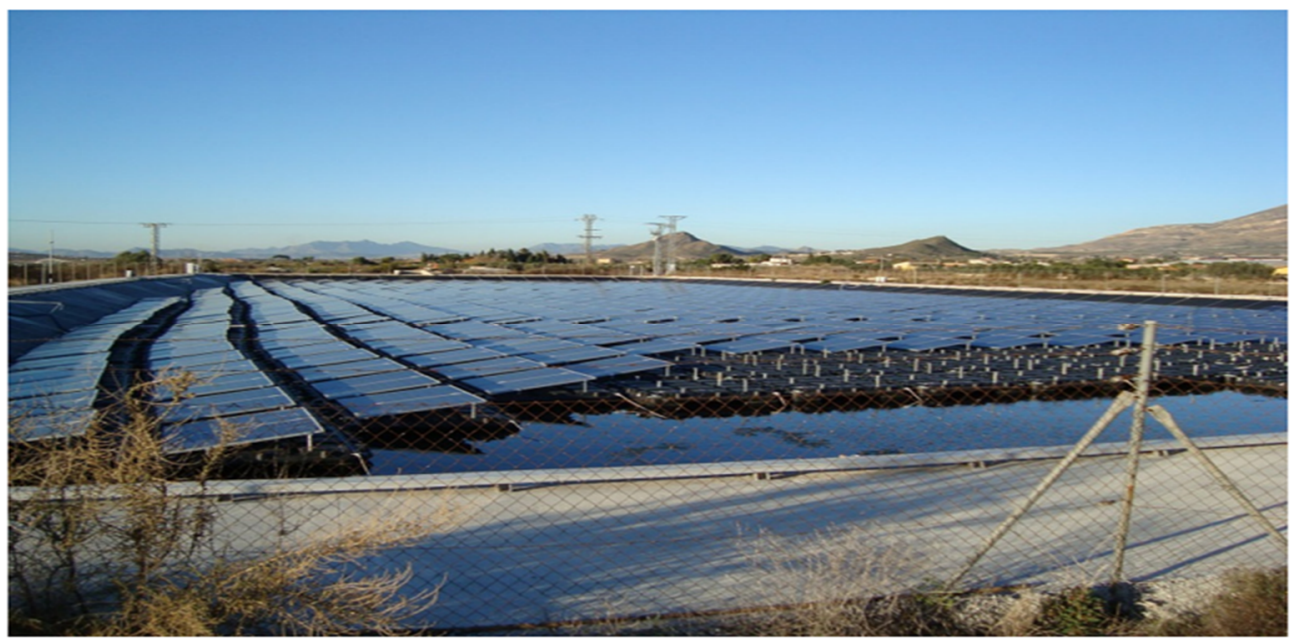

Figure 11. FPV system installed on the irrigation water reservoir in Spain [34].

The possible FPV installations at Jablanica lake located in Bosnia aim to supply clean energy generation with an annual approximate potential of $36.55 \mathrm{GWh}$ for the installed capacity of 30 MW [38]. FPV power plants located at Shek Pik and Plover Cove reservoirs in Hong Kong have $100 \mathrm{~kW}$ power capacity. It is declared that the energy generation potential of these FPV systems depicted in Figure 12 is more than 120,000 kWh per year [39].

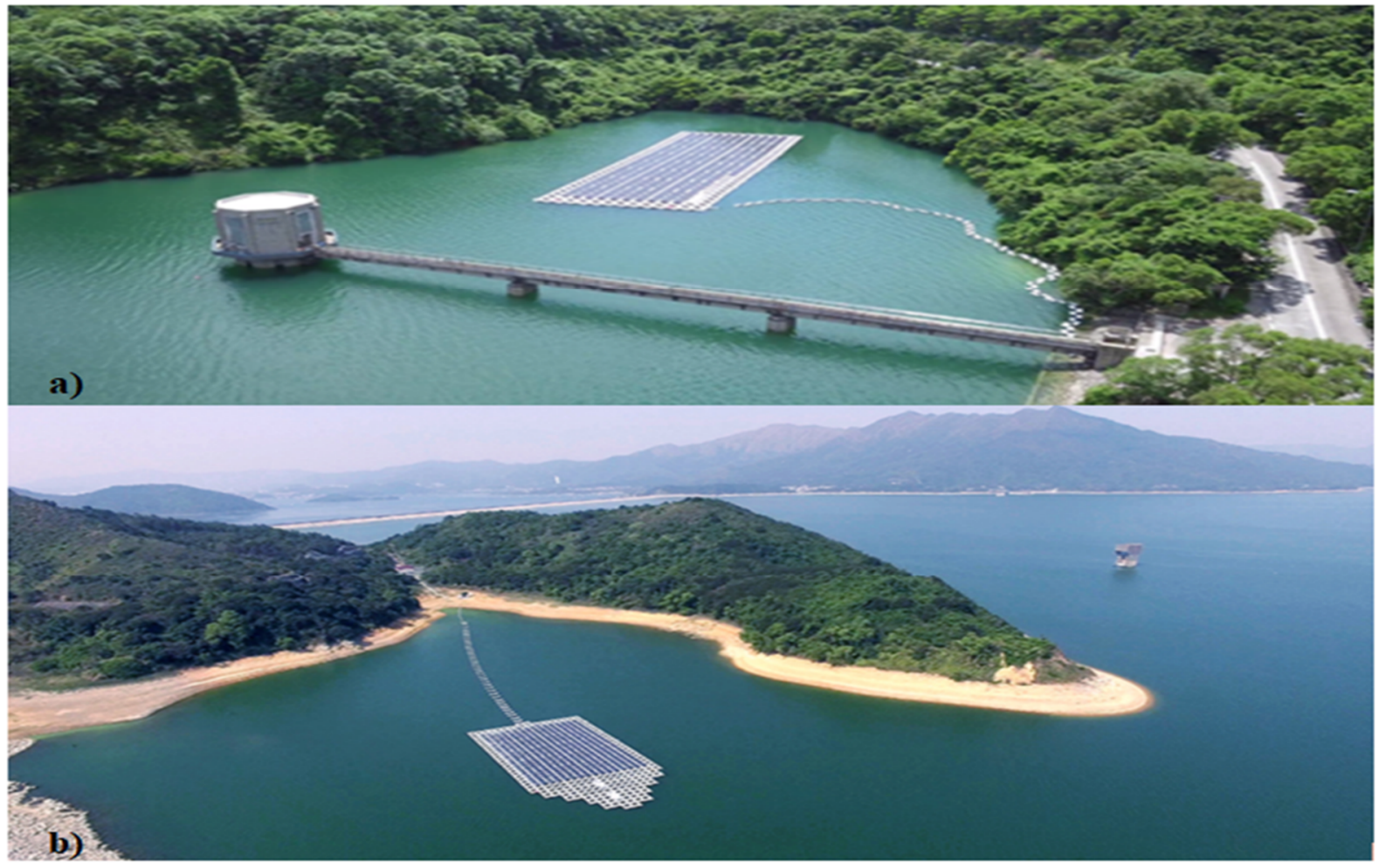

Figure 12. $100 \mathrm{~kW}$ FPV power plants located at (a) Shek Pik and (b) Plover Cove reservoirs [39].

\subsection{Reduction in Evaporation Rates}

One of the main benefits of FPV installations on the water reservoir can be described as the water saving achieved by reducing the evaporation due to providing coverage through 
FPV systems as illustrated in Figure $13[34,40]$. Based on the analysis with respect to installing FPV systems on the water reservoir, it is declared that the amount of water saving gained by reducing evaporation by means of FPV is determined to be nearly $5000 \mathrm{~m}^{3} /$ year, and this amount accounts for $25 \%$ of the whole capacity of the reservoir [41]. The study conducted by Mittal et al. [37] investigated the reduction in evaporation due to FPV installation at lakes located in India. The maximum water saving owing to a $27 \mathrm{MW}$ FPV covering $20 \%$ of the Man Sagar Lake surface area was determined to be 496 million liters annually as provided in Table 2 .

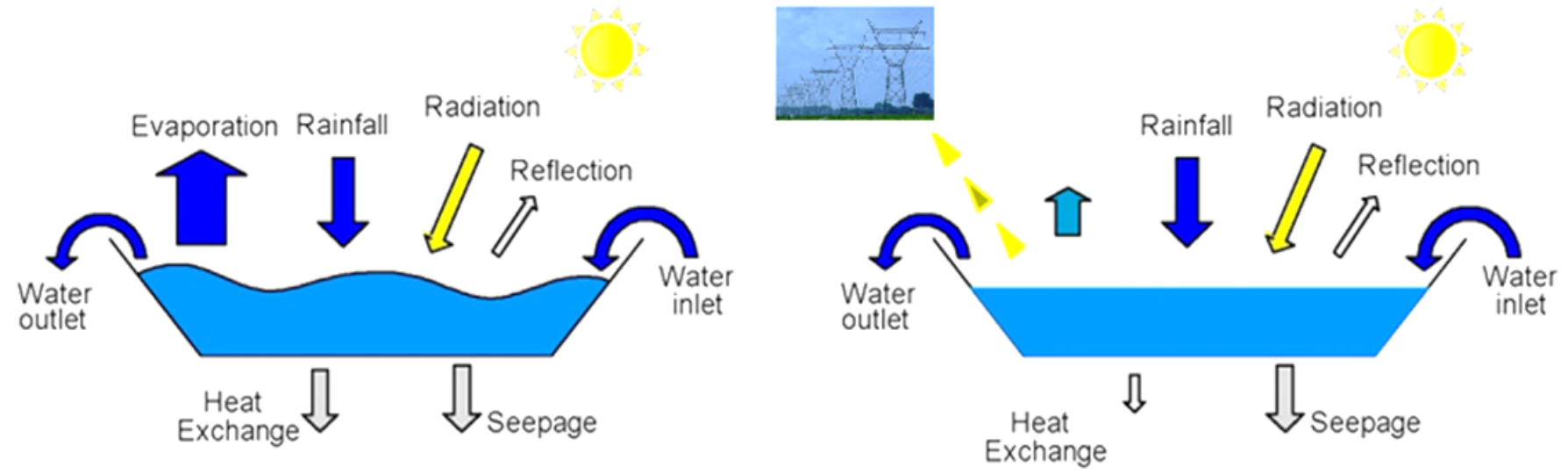

Figure 13. Illustrations of water reservoirs with/out FPV installations in terms of energy saving [34].

Table 2. Energy generation and water-saving features of the FPV system installed at the Man Sagar Lake [37].

\begin{tabular}{ccccc}
\hline $\begin{array}{c}\text { Covered Area of Man } \\
\text { Sagar Lake (139 ha) }\end{array}$ & $\begin{array}{c}\text { Energy Generation } \\
\text { (MWh/Year) }\end{array}$ & $\begin{array}{c}\text { Installed Capacity } \\
\text { (MW) }\end{array}$ & $\begin{array}{c}\text { Evaporation without } \\
\text { FPV (ML/Year) }\end{array}$ & $\begin{array}{c}\text { Water Saving Due to } \\
\text { FPV (ML/Year) }\end{array}$ \\
\hline $5 \%$ & 12,135 & 6 & 177 & 124 \\
$10 \%$ & 26,292 & 13 & 354 & 248 \\
$15 \%$ & 40,449 & 20 & 531 & 372 \\
$20 \%$ & 54,606 & 27 & 708 & 496 \\
\hline
\end{tabular}

In another study [42], the influence of FPV installations at wastewater basins was theoretically analyzed as shown in Table 3. It should be emphasized that the water saving through FPV systems is at a remarkable level. The installation of FPVs at hydroelectric power plants (HPPs) was analyzed in China. A feasibility study was conducted for 46,758 stations regarding the role of FPVs in reducing the evaporation from the water surface [33]. The results indicate that the water saving is estimated to be approximately $2 \times 10^{27} \mathrm{~m}^{3}$ through the covering of $2500 \mathrm{~km}^{2}$ water basins. The project related to a $1 \mathrm{MW}$ FPV installed at the Kota Barrage and Kishor Sagar Lake was analyzed in terms of water saving, energy generation, and the decline in carbon emissions [43]. It was reported that the water saving is expected to be 37 million liters/year from both potential installations. A similar study was performed for Kaylana Lake to reveal an increase in water saving via utilization of FPV systems [44]. According to the results, the water saving amount based on reducing the evaporation was determined to be 191,174 million liters/year with 1 MW FPV installations [45]. 
Table 3. Reduction in evaporation rates at wastewater basins through FPV installations [42].

\begin{tabular}{|c|c|c|c|c|}
\hline Location & $\begin{array}{c}\text { Surface Area } \\
\left(\mathrm{m}^{2}\right)\end{array}$ & Installed Power (kW) & $\begin{array}{c}\text { Energy Generation } \\
\text { (MWh/Year) }\end{array}$ & $\begin{array}{c}\text { Water Saving } \\
\left(\mathrm{m}^{3} / \text { Year }\right)\end{array}$ \\
\hline Bolivar & 640,000 & 75,000 & 133,875 & $1,152,000$ \\
\hline Goolwa & 68,775 & 9313 & 16,391 & 123,795 \\
\hline Lilydale & 86,400 & 8467 & 13,971 & 138,240 \\
\hline
\end{tabular}

\section{Applications of FPV Systems}

Water reservoirs can be split into three categories composed of freshwater resources (FWR), human-made resources (MMR), and basin surfaces of hydropower plants (HPPs). The data based on worldwide water resources are depicted in Table 4 [46].

Table 4. Worldwide water reservoirs [46].

\begin{tabular}{|c|c|c|c|}
\hline & FWR, $\mathbf{k m}^{2}$ & MMR, $\mathbf{k m}^{2}$ & HPPs, $\mathrm{km}^{2}$ \\
\hline Africa & 540,030 & 46,499 & 24,197 \\
\hline America Central & 58,801 & 4161 & 2899 \\
\hline America South & 381,710 & 65,000 & 53,863 \\
\hline Asia South East & 153,490 & 32,231 & 22,929 \\
\hline Asia South Without India & 48,320 & 1238 & 1081 \\
\hline Australia and New Zeeland & 58,920 & 4695 & 1216 \\
\hline Canada & 891,163 & 97,914 & 95,224 \\
\hline China & 270,550 & 12,979 & 7454 \\
\hline Europe (North) & 178,156 & 30,267 & 24,724 \\
\hline Europe (South) & 19,612 & 3091 & 2066 \\
\hline India & 314,00 & 102,775 & 13,361 \\
\hline Japan & 14,430 & 1394 & 130 \\
\hline Middle East & 140,190 & 26,259 & 10,775 \\
\hline Russia & 720,500 & 85,408 & 84,761 \\
\hline Turkestan & 76,110 & 17,247 & 14,582 \\
\hline USA & 685,924 & 43,904 & 21,686 \\
\hline Total & $4,550,906$ & 573,377 & 380,948 \\
\hline
\end{tabular}

\subsection{Hydropower Plants}

The integration of FPV systems with hydropower plants provides some advantages in practice. For instance, it is known that existing HPPs utilize grid connectors and power generators. The availability of this equipment leads to a reduction in the cost of FPVs. Moreover, in warm regions, the energy production from HPPs is reduced due to the seasonal water level of the dam during the summer. However, the PV modules in the said regions work with the maximum capacity to produce energy. In this way, the fluctuation in the energy generation can be compensated [47].

The research conducted by Cazzaniga et al. [47] underlines the notable growth in renewable energy generation due to the integration of FPV with HPPs. It is reported that if FPV is applied to $2.4 \%$ of the global HPP basin surfaces, the growth in total energy generation is predicted to be $35.9 \%$. There have been many attempts to integrate FPVs with HPPs at a global scale. One such project in Brazil reveals that the FPV system installed on the Balbina Dam has an energy-generating capacity of $970 \mathrm{GWh} /$ year. It is reported that the total energy generation can be enhanced by more than 35\% through a hybrid FPV system without any hazardous effects on the environment [46].

\subsection{Water Treatment}

The basins of wastewater treatment facilities are commonly known to spread across large areas but are very shallow water surfaces compared with lakes, etc. The basins are used to transform the wastewater into irrigation water through aerobic processes. While applying FPV to the basins, water saving is provided by reducing the evaporation rate, 
and the sickly smell arising from the wastewater basin can be reduced, bringing about an increase in aerobic processes [42]. An FPV station with a capacity of 6.3 MW installed at a water treatment facility in London is stated to generate energy which is roughly equivalent to the energy demands of 1800 dwellings [48]. An FPV power plant (having $4.4 \mathrm{MW}$ power capacity) located at the Bordentown Avenue water treatment facility is reported to meet its own energy demand with an electricity generation capacity of 5 GWh/year [49].

\subsection{Irrigation Reservoir}

Compared with the rest of the applications, irrigations or drinking water reservoirs are more popular for the installation of FPV systems for generating electricity [17]. For instance, it is reported that more FPV power plants are installed on irrigation reservoirs among the other suitable water bodies in Japan. An FPV power plant located in Hyogo was deployed to the irrigation reservoir spreading over 2.8 ha. The coverage of the FPV accounts for nearly $43 \%$ of the water surface as shown in Figure 14 [50]. In Brazil, a $305 \mathrm{~kW}$ FPV power station covering more than $45 \%$ of the agricultural irrigation reservoir is composed of 1150 PV panels [51].

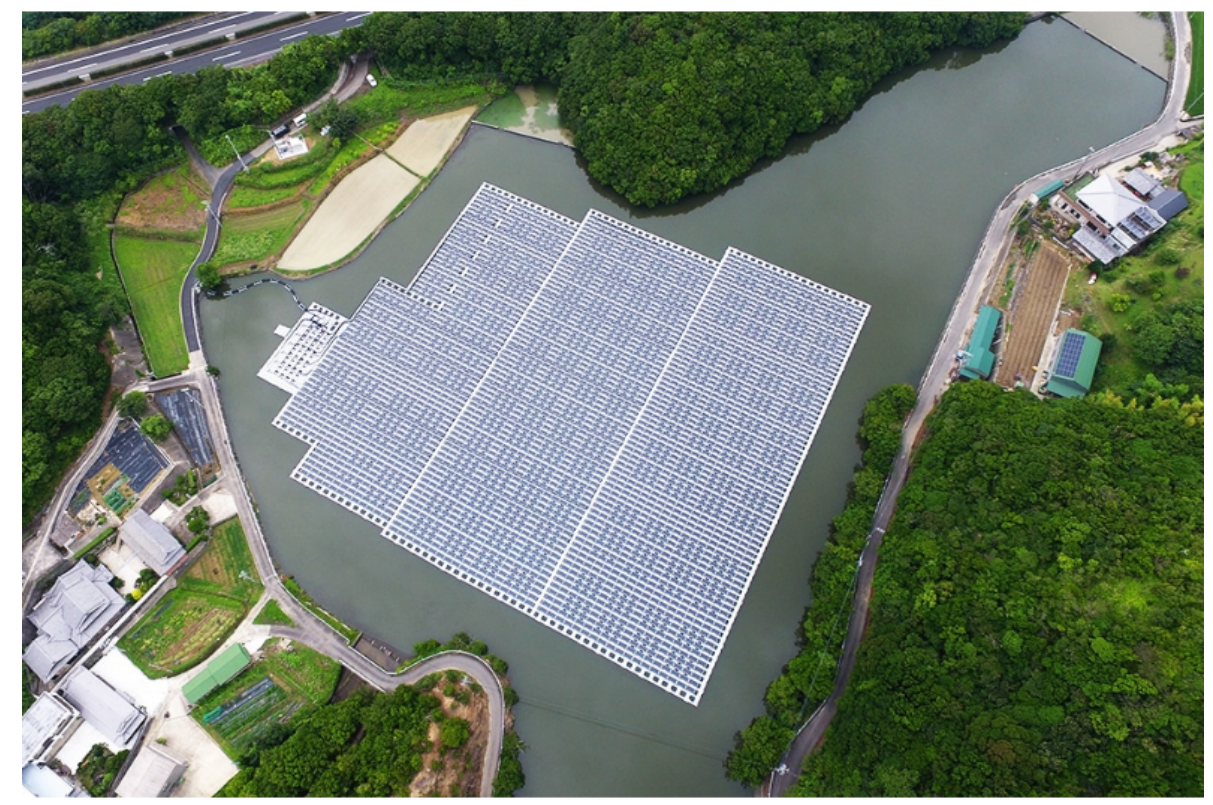

Figure 14. Hikuni Ike, 1.3 MW FPV which has been in operation since 2019 [50].

\subsection{Mining Water Basins}

An FPV system can be installed on water bodies belonging to active and former mining sites. For active mining sites, the consumption of energy and water attracts attention. So as to mitigate the aforesaid resource consumption, an FPV is considered as an alternative to generate clean energy and to reduce the evaporation from the water surface [52]. The abandoned quarries and mining sites are informed to have huge water bodies allowing the possibility of FPV installations to produce renewable energy and to mitigate carbon emissions [53]. In Chile, an $85 \mathrm{~kW}$ FPV covering $110 \mathrm{~m}^{2}$ of the water surface to improve the efficiency of the facility is installed on mining water bodies placed at $3500 \mathrm{~m}$ above sea level. The reduction in evaporation is determined to be $80 \%$ relative to the findings [54]. A $70 \mathrm{MW}$ FPV power plant is planned to be installed on 63 ha of the collapsed coal mining water basins in China. The potential energy production is expected to be equivalent to meeting the energy demand of 21,000 dwellings [53]. After examining the applications of the FPV station, the main factors in the designation of water reservoirs suitable for installation of FPV systems are depicted in Table 5. 
Table 5. The factors in the designation of water reservoirs suitable for installation of FPV systems [17].

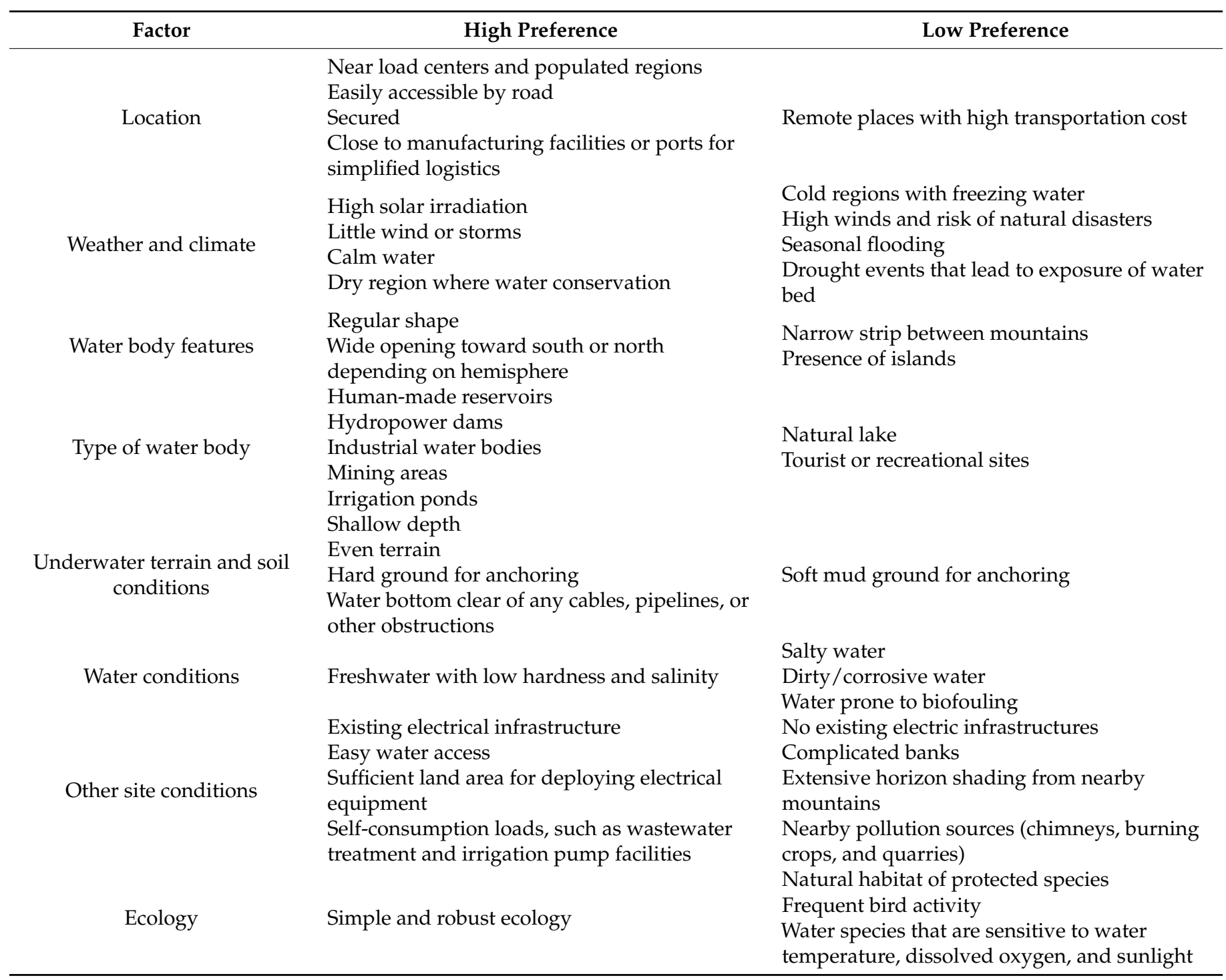

\section{Comparison of FPVs and LBPVs}

Energy generation with respect to FPV power plants shows higher performance compared with LBPV. Depending on this circumstance, many researchers focus on the comparisons in terms of energy production from FPV and LBPV. Table 6 presents the comparison between FPV and LBPV systems in terms of energy efficiency.

For instance, the case study carried out by Choi et al. [55] investigates two different FPV plants installed in Hapcheon shown in Figure 15 [56] and an LBPV located at Haman. Moreover, the energy generation from the FPV is compared with the generation based on the LBPV. According to the results, the efficiency of the FPV is found to be $10 \%$ better than that of the LBPV. A further study conducted in Korea evaluated the energy generation and the capacity factor of FPVs and LBPVs, between July and September of 2010 [57]. The capacity factor ratio of FPVs and LBPVs was determined to be 1.1 and 0.8 from July to September, respectively. 


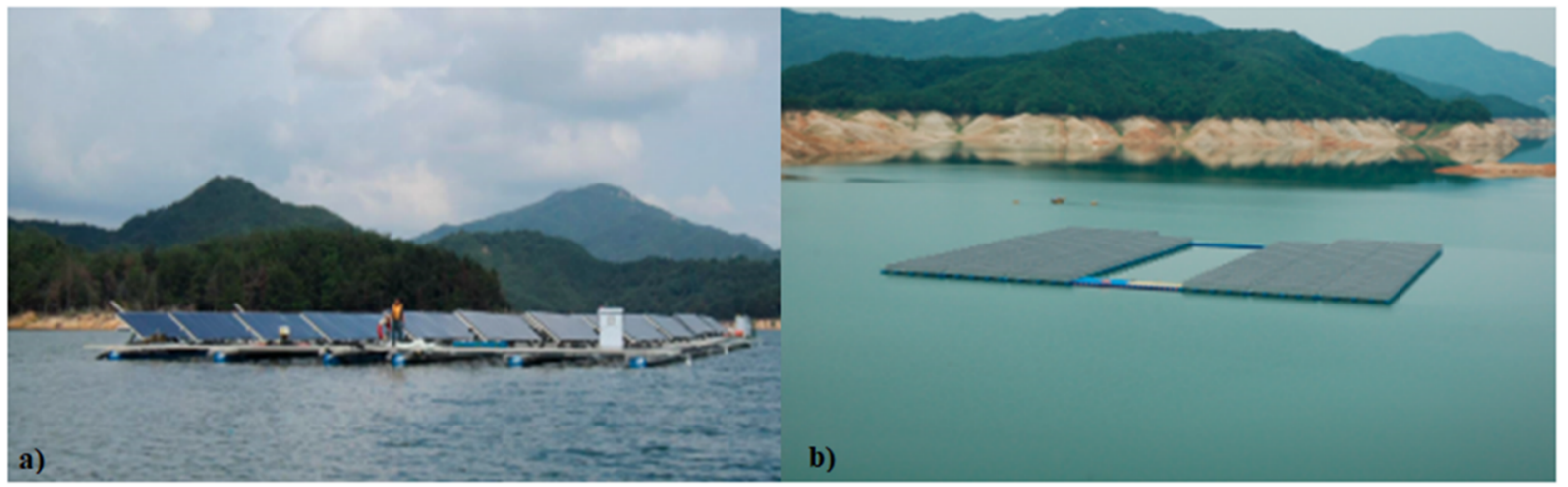

Figure 15. (a) $100 \mathrm{~kW}$ FPV and (b) $500 \mathrm{~kW}$ FPV at the Hapcheon Dam [56].

The FPV shown in Figure 16 and conventional PV panels were analyzed in three different solar radiation levels of 417,617 , and $834 \mathrm{~W} / \mathrm{m}^{2}$ [58]. The average efficiency of the FPV and PV at $417 \mathrm{~W} / \mathrm{m}^{2}$ is determined to be 4.38 and $4.22 \%$, respectively. Moreover, in comparison with conventional PVs, the efficiency of the FPV is found to be about $3.8 \%$ higher. The increase in solar radiation has profound effects on power generation and the efficiency of the systems. In line with the results, power generation and average efficiency of the FPV are found to be $5.04 \mathrm{~W}$ and $5.5 \%$. It is also stated that the efficiency belonging to the FPV reaches $14.6 \%$ at $834 \mathrm{~W} / \mathrm{m}^{2}$.

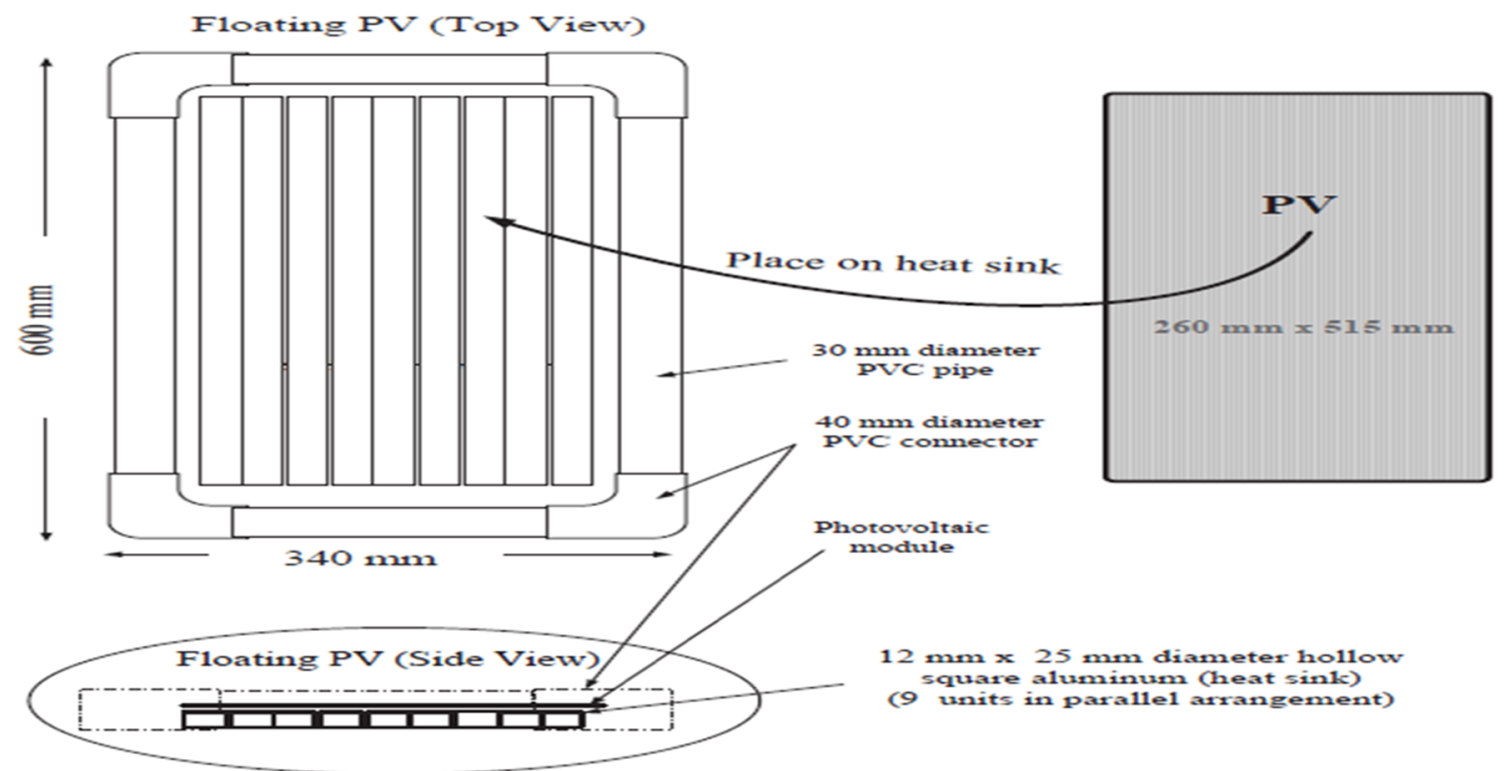

Figure 16. Schematic illustrations of FPV for experimental analysis [58].

The research carried out by Azmi et al. [58] investigates the power gain of the FPV and LBPV in a laboratory by using an experimental simulator. The results reveal that the FPV and LBPV can generate 1190 and $1030 \mathrm{~W}$, respectively, when exposed to a solar intensity of $896 \mathrm{~W} / \mathrm{m}^{2}$ [59]. In another study, the capacity factor of the FPV and LBPV is investigated by Yadav et al. [60]. According to the results, the FPV performs nearly 7\% better than conventional LBPVs. Annual energy generation performance is also evaluated for the FPV and LBPV. The findings indicate that the potential energy generation from FPV and LBPV is estimated to be 1715.57 and $1673.98 \mathrm{MWh} /$ year, respectively [44]. A numerical attempt compares the energy generation from $8.3 \mathrm{~kW}$ at each of the FPV and LBPV. It is mentioned that the FPV generates nearly $2.5 \%$ more energy compared with the LBPV (12,291 kWh/year) [45]. 
Table 6. The comparison between FPV and LBPV in terms of energy efficiency.

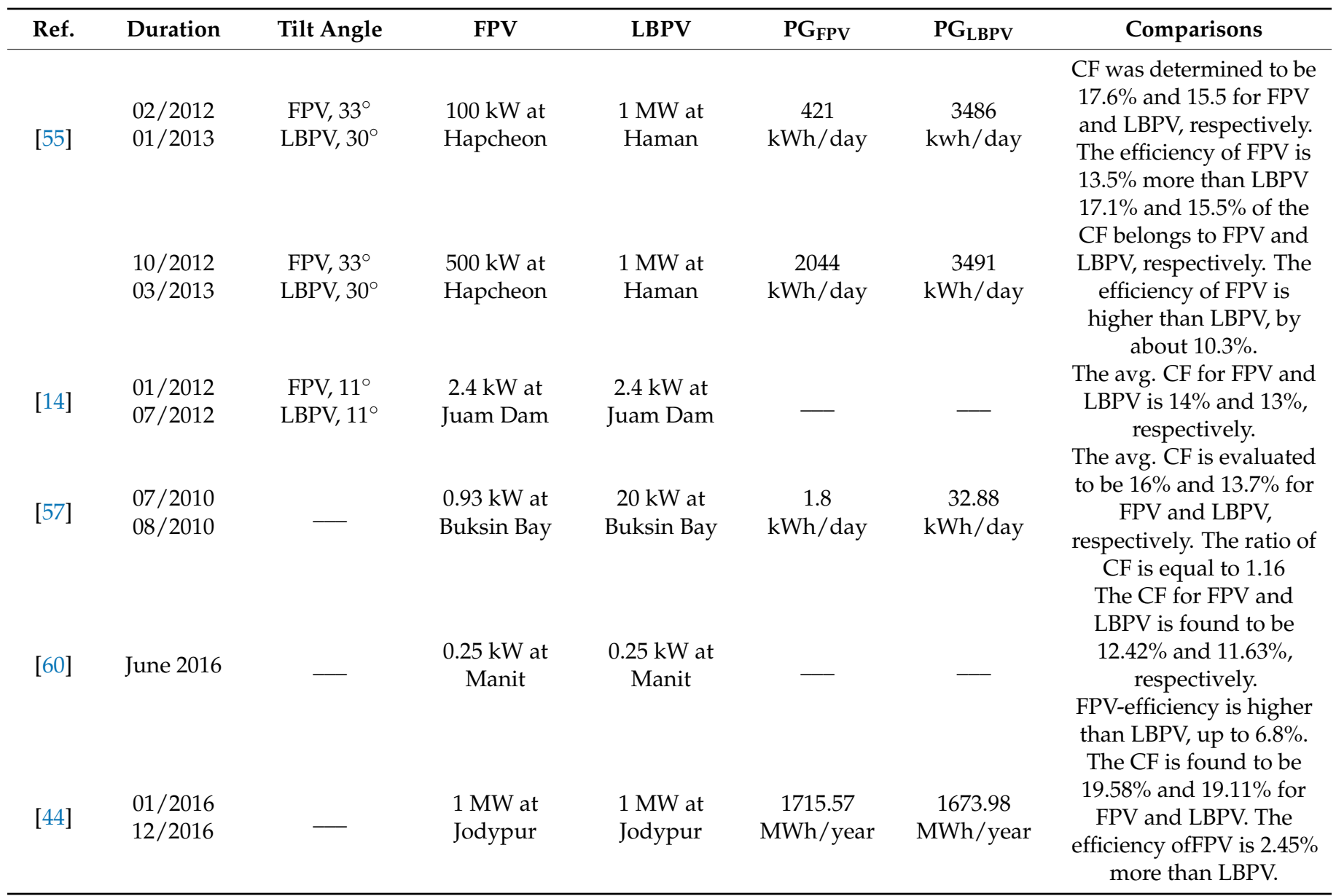

Golroodbari and Sark [61] carried out a simulation study for the purpose of comparing the performances of FPV and LBPVs. They developed a mathematical model for both FPV and LBPV and characterized different tilt angles. According to the results, they demonstrated that tilt angles of FPV are a very important parameter on the performance of the system. For the optimal tilt angle of FPV, the FPVs have better performance by about $12.96 \%$ than LBPVs, on average, on an annual basis.

\section{FPV Market and Potential}

The increase in global FPV applications depends on some parameters, notably, the solar irradiance potential, the convenience of the water resources for the FPV, and the distance between the FPV plants and the power lines. Based on the report declared by the World Bank Organization, the potential of FPV power plants were evaluated to utilize the water reservoirs existing in continents. The energy capacity and possible energy yielding are indicated in Table 7 [13]. If FPV systems are installed on 1\% of the total global water surface areas, the required FPV power capacity is estimated to be 400 GW. It was also declared that the power capacity of FPV plants already in operation reached roughly $1.3 \mathrm{GW}$ at the end of 2018 [17]. Briefly, the global FPV market can be deduced as a new market for the renewable energy sector. 
Table 7. The potential energy generation from FPV installed on suitable water reservoirs [13].

\begin{tabular}{|c|c|c|c|c|c|c|c|c|}
\hline \multirow[t]{2}{*}{ Continent } & \multirow{2}{*}{$\begin{array}{l}\text { Total Surface } \\
\text { Area } \\
\left(\mathrm{km}^{2}\right)\end{array}$} & \multirow{2}{*}{$\begin{array}{l}\text { Number of } \\
\text { Water } \\
\text { Reservoirs }\end{array}$} & \multicolumn{3}{|c|}{$\begin{array}{c}\text { Total FPV Capacity (GW) (the } \\
\text { Coverage Rate of the Water Surface } \\
\text { Area with FPV) }\end{array}$} & \multicolumn{3}{|c|}{$\begin{array}{c}\text { Total Potential Energy Generation } \\
\text { (GWh/Year) (the Coverage Rate of the Water } \\
\text { Surface Area with FPV) }\end{array}$} \\
\hline & & & $1 \%$ & $5 \%$ & $10 \%$ & $1 \%$ & $5 \%$ & $10 \%$ \\
\hline Asia & 115,621 & 2.041 & 116 & 578 & 1156 & 128,691 & 643,456 & $1,286,911$ \\
\hline Africa & 101,130 & 724 & 101 & 506 & 1011 & 167,165 & 835,824 & $1,671,648$ \\
\hline Europe & 20,424 & 1082 & 20 & 102 & 204 & 19,574 & 97,868 & 195,736 \\
\hline N. America & 126,017 & 2248 & 126 & 630 & 1260 & 140,815 & 704,076 & $1,408,163$ \\
\hline Oceania & 4991 & 254 & 5 & 25 & 50 & 6713 & 33,565 & 67,131 \\
\hline S. America & 36,271 & 299 & 36 & 181 & 363 & 58,151 & 290,753 & 581,507 \\
\hline Total & 404,454 & 6648 & 404 & 2022 & 4044 & 521,109 & $2,605,542$ & $5,211,086$ \\
\hline
\end{tabular}

The FPV power station installed in Anhui, China, is known as having the world's largest FPV power capacity. It is reported that the payback period of this FPV station is expected to be less than 7 years [62]. Furthermore, it is stated that the carbon saving is expected to be nearly 199,500 tons annually. The energy demand of 94,000 dwellings located in urban and rural areas would be met by generated electricity from this station [63]. The FPV station is considered as an applicable technology for countries having more water bodies than land. Many countries deploy the FPV systems to generate electricity. Table 8 also demonstrates the operated FPV stations that are more than $5 \mathrm{MW}$ of the installation capacity placed on the world [64-79].

Table 8. FPV (power capacity $\geq 5 \mathrm{MW}$ ) power plants in the world.

\begin{tabular}{|c|c|c|c|c|c|c|}
\hline $\begin{array}{l}\text { Power } \\
\text { Capacity } \\
\text { (MW) }\end{array}$ & $\begin{array}{l}\text { Water Basins and } \\
\text { Location }\end{array}$ & Country & $\begin{array}{l}\text { Grid- } \\
\text { Connection } \\
\text { Year }\end{array}$ & Deployed by & Description & Ref. \\
\hline 150 & $\begin{array}{c}\text { Coal mining subsidence } \\
\text { area, Huainan }\end{array}$ & China & 2018 & $\begin{array}{l}\text { Three Gorges } \\
\text { New Energy }\end{array}$ & \multirow{5}{*}{$\begin{array}{c}\text { Installation cost of } \$ \\
23.8 \text { million } \\
220 \mathrm{GW} / \text { year of energy } \\
\text { generation } \\
3.04 \text { billion } \mathrm{kWh} \text { over } \\
25 \text { years }\end{array}$} & [64] \\
\hline 150 & $\begin{array}{l}\text { Coal mining subsidence } \\
\text { area, Huainan }\end{array}$ & China & 2018 & Sungrow & & [65] \\
\hline 130 & $\begin{array}{c}\text { Coal mining subsidence } \\
\text { area, Anhui }\end{array}$ & China & 2018 & Trinasolar & & {$[66]$} \\
\hline 102 & $\begin{array}{l}\text { Coal mining subsidence } \\
\text { area, Huainan }\end{array}$ & China & 2017 & Sungrow & & [67] \\
\hline 100 & $\begin{array}{l}\text { Coal mining subsidence } \\
\text { area, Jinxing }\end{array}$ & China & 2018 & Sungrow & & [67] \\
\hline 70 & Mine lake, Anhui & China & 2018 & Ciel and Terre & \multirow[t]{2}{*}{$\begin{array}{l}\text { 194,731 floating solar } \\
\text { panels }\end{array}$} & [68] \\
\hline 50 & $\begin{array}{l}\text { Coal mining subsidence } \\
\text { area, Jinxing }\end{array}$ & China & 2017 & Sungrow & & [67] \\
\hline 40 & Coal mine, Huaibei & China & 2017 & Trinasolar & \multirow[t]{2}{*}{$\begin{array}{c}15 \mathrm{~km}^{2} \text { of water } \\
\text { surfaces }\end{array}$} & [69] \\
\hline 40 & $\begin{array}{l}\text { Coal mining subsidence } \\
\text { area, Huainan }\end{array}$ & China & 2017 & Sungrow & & [68] \\
\hline 32.6 & Mine lake & China & 2018 & Cile and Terre & \multirow[t]{2}{*}{$\begin{array}{c}\text { Covering } 20 \% \text { of water } \\
\text { surface }\end{array}$} & {$[70]$} \\
\hline 31 & $\begin{array}{l}\text { Coal mining subsidence } \\
\text { area, Jinxing }\end{array}$ & China & 2017 & Sungrow & & [67] \\
\hline 27.4 & Bomhofsplas, Zwolle & Netherlands & 2020 & Baywa & $\begin{array}{l}\text { Meeting the } \\
\text { consumption of } \\
7800 \text { dwellings }\end{array}$ & [71] \\
\hline
\end{tabular}


Table 8. Cont.

\begin{tabular}{|c|c|c|c|c|c|c|}
\hline $\begin{array}{l}\text { Power } \\
\text { Capacity } \\
\text { (MW) }\end{array}$ & $\begin{array}{l}\text { Water Basins and } \\
\text { Location }\end{array}$ & Country & $\begin{array}{c}\text { Grid- } \\
\text { Connection } \\
\text { Year }\end{array}$ & Deployed by & Description & Ref. \\
\hline 20 & $\begin{array}{l}\text { Coal mining subsidence } \\
\text { area, Huainan }\end{array}$ & China & 2016 & - & - & [13] \\
\hline 18.7 & Gunsan Retarding Basin & Korea & 2018 & Scotra & $\begin{array}{l}\text { Meeting the energy } \\
\text { demand of } 7450 \text { houses }\end{array}$ & {$[72]$} \\
\hline 17 & Piolec & France & 2019 & Akuo Energy & $\begin{array}{l}\text { Meeting energy } \\
\text { demands of } \\
4773 \text { dwellings }\end{array}$ & [73] \\
\hline 14.5 & Sekdoorn, Zwolle & Netherlands & 2019 & Baywa & $\begin{array}{l}6465 \text { tones of carbon } \\
\text { saving annually }\end{array}$ & [71] \\
\hline 13.7 & Yamakura Dam reservoir & Japan & 2018 & Ciel and Terre & $\begin{array}{l}\text { Installed on } 18 \text { ha of } \\
\text { water surface }\end{array}$ & [74] \\
\hline 9.9 & Water storage reservoir, & Taiwan & 2018 & Ciel and Terre & Covering $92,000 \mathrm{~m}^{2}$ & [75] \\
\hline 9.9 & $\begin{array}{l}\text { Agongdian } \\
\text { Irrigation reservoir, Pei }\end{array}$ & China & 2017 & Ciel and Terre & $\begin{array}{l}\text { Covering } 29 \% \text { of the } \\
\text { water basin }\end{array}$ & {$[76]$} \\
\hline 8.4 & $\begin{array}{l}\text { County } \\
\text { Tynaarlo, Drenthe }\end{array}$ & Netherlands & 2019 & Baywa & $\begin{array}{l}7669 \mathrm{MWh} / \text { year } \\
\text { energy production }\end{array}$ & [71] \\
\hline 7.5 & Irrigation, Saitama & Japan & 2015 & Ciel and Terre & $\begin{array}{l}\text { Covering } 57 \% \text { of water } \\
\text { surface }\end{array}$ & [77] \\
\hline 6.7 & Mine Lake, Shandong & China & 2018 & Ciel and Terre & $\begin{array}{l}\text { Covering } 9.5 \% \text { of water } \\
\text { surface }\end{array}$ & [78] \\
\hline 6.3 & $\begin{array}{c}\text { Drinking water reservoir, } \\
\text { London }\end{array}$ & U.K. & 2016 & $\begin{array}{l}\text { Ciel and } \\
\text { Terre }\end{array}$ & $\begin{array}{l}\text { Covering } 5 \% \text { of water } \\
\text { surface }\end{array}$ & [79] \\
\hline
\end{tabular}

Many countries plan to increase energy generation based on FPV systems. Due to this, such countries are increasing commercial agreements and investments with regard to plant installations depending on the convenience of the water sources for the installation of FPV stations. For instance, the FPV project with $150 \mathrm{MW}$ of power capacity being presented as the first FPV project for Malaysia is expected to be completed in 2020. The PV panels are supplied by Chinese solar panel manufacturers [80]. In another project, it is planned to install an FPV with 145 MW of power capacity on a 225 ha area of the Cirata Reservoir in Indonesia. It is also reported that the date of connecting the FPV to the grid would be in 2022 [81]. Based on the study carried out by the Energy and Resources Institute, the water reservoir of India is more than $18,000 \mathrm{~km}^{2}$, and the potential of FPV power capacity is also determined to be $280 \mathrm{GW}$ [82]. In addition, it is expected to improve the FPV power capacity by up to $1 \mathrm{GW}$ by the Maharashtra State electricity distribution company [13]. The world's largest FPV station installation is planned on the coast of the Yellow sea in Korea. The power capacity is estimated to be $2.1 \mathrm{GW}$ and the installation cost is determined to be nearly \$ 3.36 million [83].

\section{Environmental Impacts}

Many researchers focus on the effects of FPV on both energy generation and the environment. FPV installed on water surfaces has positive impacts on the environment such as carbon saving and water saving obtained from preventing the evaporation of water surfaces [84-86]. Al-Widyan et al. [87] conducted an experimental study to observe the effect of FPVs on water quality and energy efficiency. They tested water quality parameters by collecting samples from August 2020 to February 2021 with the help of a spectrophotometer. The results of the experimental study revealed that an increase in the total water quality was observed with a decrease in algae biomass. In addition, a decrease in the $\mathrm{PH}$ values measured at certain points, an improvement in clarity, and an increase in the amount of organic carbon were observed. Some studies examining the reduction in carbon emissions by installing FPV systems are presented in Table 9 including the type of water basins, covering areas, and the amount of carbon saving. On the other hand, covering 
the water surfaces with FPV is stated to have possible effects on water quality and water life as follows:

- The occurrence of water layers depending on the change in temperature

- Changes in oxygen levels of the water affect aquatic habitats due to not meeting the oxygen demands

- Prevention of wind effects on the dynamic systems existing on water surfaces (providing heat transfer of the whole reservoir)

- Reduction in the growth rates of marine life

- Changes in water odor and taste and the increase in possible health problems based on the metals at the bottom of the reservoir

- The systems do not harm biodiversity, and in particular, birds are not harmed, in addition to establishing a good balance with aquatic fauna $[84,85]$.

- Blue-green algae result in the corrosion of metals because of the existence of dissolved oxygen levels [88,89].

Table 9. Carbon saving by virtue of FPV installations.

\begin{tabular}{ccccc}
\hline Ref. & Research & Covering Area $\left.\mathbf{( m}^{2}\right)$ & Water Basin & Carbon Saving \\
\hline$[41]$ & Experimental & 4490 & Irrigation water reservoir & 1454.19 tons of $\mathrm{CO}_{2}$ saving over the \\
lifetime of $\mathrm{FPV}$ & \\
{$[35]$} & Simulation & 87,650 & Open-pit limestone mine & 471.21 tons of $\mathrm{CO}_{2} /$ year \\
{$[36]$} & Simulation & - & 1134 water reservoirs in & $1,294,450$ tons of $\mathrm{CO}_{2} /$ year \\
{$[43]$} & Simulation & 10,000 each of them & Lake and barrage & 1773 and 1714 tons of $\mathrm{CO}_{2} /$ year \\
{$[45]$} & Simulation & 50 & Lake & 14.44 tons of $\mathrm{CO}_{2} /$ year \\
{$[39]$} & Power plants & - & Water reservoir & Nearly 85 tons of $\mathrm{CO}_{2} /$ year \\
\hline
\end{tabular}

When the life cycle of the FPV systems is evaluated, the possible effects of FPV on the environment are pointed out as demonstrated in Table 10 [17].

Table 10. Possible environmental impacts of FPVs during construction and operation [17].

\begin{tabular}{ll}
\hline \multicolumn{1}{c}{ Stage } & \multicolumn{1}{c}{ Effects } \\
\hline & Short-term air pollution from project construction equipment \\
& Noise, affecting people and wildlife, from project construction equipment \\
Installation and decommissioning & Turbidity from installation and dismantling of mooring and anchoring systems \\
(short and long-term effects) & Potential release of oil and lubricant spills related to project construction equipment \\
& Loss of habitat and marine species \\
& The increase in waste during construction and delivery of the equipment \\
& The failure in water quality: \\
& Increased temperature \\
& Decreased dissolved oxygen \\
& Limited mixing \\
& Leaching/chemical risk \\
& Loss of benthic habitat \\
Impact on primary production \\
(long-term effects) & Loss of avian wildlife \\
& Loss of marine species \\
Loss of aesthetic value
\end{tabular}

\section{Challenges}

Although the performance of the FPV is greater than LBPV in terms of energy production, the installation cost of FPVs is reported to be more than $\$ 100,000$ per MW. So it is highlighted that the cost is considered as the main drawback of FPV systems [90]. Based on the report conducted by the Fraunhofer Institute for solar energy systems, the potential of FPV installation in Germany is estimated to be nearly $56 \mathrm{GW}$. The handicap is 
that the installation cost of FPV is $10-15 \%$ more than the LBPV. This obstacle avoids the increase in FPV systems which could be overcome by providing incentive packages [91]. In terms of capital investment, FPV and LBPV that are assumed as operating under the same conditions are theoretically compared. On the basis of the findings, it is indicated that the FPV cost is roughly 18\% more expensive than the LBPV cost [13]. In this investigation, the power capacity of the systems is considered to be $50 \mathrm{MW}$. The analyses of total capital investments pointed out in Table 11 are carried out by using this assumption.

Table 11. The capital expenditures (CAPEX) of FPV and LBPV [13].

\begin{tabular}{ccc}
\hline CAPEX Component & FPV 50 MW (\$/W) & LBPV 50 MW (\$/W) \\
\hline Modules & 0.25 & 0.25 \\
Inverters & 0.06 & 0.06 \\
Mounting system & 0.15 & 0.10 \\
Balance of the systems & 0.13 & 0.08 \\
Design and construction & 0.14 & 0.13 \\
Total CAPEX & 0.73 & 0.62 \\
\hline
\end{tabular}

The degradation of FPVs is regarded as being crucial due to the effects of humidity on the PV panels compared with LBPVs [90]. As remembered, environmental conditions profoundly influence the performance of PVs. These conditions consist of humidity, snow, cold, heat, etc., result in product failure. It is also stated that the degradation of FPVs can increase depending on temperature and humidity such as corrosion, ribbon fatigue, and back sheet hydrolysis. Although the evaporative cooling has a positive effect on the improvement in energy efficiency, and the longevity of FPV modules, the closeness to water surfaces of FPV leads to a huge increase in the exposure to humidity [17]. The degradations are called failure modes and can consist of potential induced degradation (PID) [92], back sheet degradation caused by chemicals descending from solar panels [93], and cell deformation and hotspots. Relative to the research with respect to PV performance, micro cracking on cells causes power losses determined to be in the range of 0.9 and $42.8 \%$ caused by the increase in hot spots [94]. Nevertheless, the drawbacks impacting the energy performance of FPVs can be lessened by the methods presented in Table 12 [17].

Table 12. Potential degradation modes and mitigation methods [17].

\begin{tabular}{ccc}
\hline Environmental Stress & Failure Mode & Mitigation Strategies \\
\hline Moisture & Corrosion & Moisture-hardened materials \\
& Hydrolysis & Back sheet: glass, aluminized \\
& PID & PID-resistant cells \\
& & System-level PID compensation \\
Mechanical stress & Interconnect fatigue & Cells and string on the neutral axis \\
& Cell cracking & Cut cells \\
& & Lower modulus encapsulants \\
& & Multi-wire interconnections \\
& Arcing $/$ melting/cracking & Less cells per bypass diode \\
Hot spot/shading & Diode failure & Higher RTI materials \\
& & Anti-soiling coatings
\end{tabular}

\section{Concluding Remarks}

Within the scope of this review, floating PV power plants are evaluated critically in terms of several performance-related aspects such as electricity production, system efficiency, reliability and sustainability, operation cost, water and carbon saving, market potential and challenges. The following bullet points can be drawn from the research: 
- Floating PVs are installed on water bodies. Owing to the direct and passive cooling effects, they keep cool in operation which yields to greater power generations compared with conventional land-based PV systems.

- Floating PV power plants have a great potential to bring down energy production expenses and to provide remarkable savings on land prices especially in island counties such as the U.K., Japan, Taiwan, and the Republic of Korea. In the aforesaid countries, valuable lands are primarily preferred for different purposes such as agriculture and livestock. Installing PV systems on water bodies such as lakes, rivers, ponds, and reservoirs also narrows the gap between conventional and solar power systems.

- Floating PV power plants perform more than $10 \%$ compared with conventional landbased PV systems. In addition, they mitigate water evaporation from water bodies by about $70 \%$. However, it needs to be noted that the investment cost of floating PV systems is slightly higher than conventional PV systems. Figures are expected to change from plant to plant since they are dependent on many environmental and operational parameters such as solar intensity, ambient temperature, wind velocity, water mass, dirt and dust level, and tilt angle of PV modules, etc.

- The floating power station installed in Anhui, China, which is known as the world's largest FPV-power capacity is reported to have a payback period of fewer than 7 years. The said plant is expected to save nearly 199,500 tons of carbon emissions annually. The energy demand of 94,000 dwellings located in urban and rural areas would be met by the electricity produced by this station.

- The influence of salt water on PV modules and the module performance are of vital importance which needs to be investigated. The degradations of floating PV systems are reported to increase depending on temperature and humidity such as corrosion, ribbon fatigue, and back sheet hydrolysis.

- Optimizing tilt angle for the PV modules in floating systems plays a notable role in annual electricity generation and system efficiency. Alternatively, floating PV systems can be operated with solar tracking units for better power generation performance.

- Offshore floating PV systems are expected to be economically feasible in the near future as a consequence of remarkable advancements in large-scale solar farms on water bodies.

- Algae growth is limited in floating PV power plants because of mitigated solar radiation, which yields to better water quality.

- Thin film PV cells have long, narrow, and rectangular cells connected in series. In addition to allowing two-dimensional current flow due to the internal structure of the cells connected in series, they are at lower temperature values in operating conditions [95]. For this reason, rather than conventional crystalline silicon PV cell technologies, thin film PV cells can be preferred to be utilized in floating PV systems which are more capable of withstanding harsh water environments.

- Geographic information systems and remote sensing techniques which are the technique of detecting and monitoring physical characteristics by measuring the radiation emitted or reflected from an area from a controlled distance, can be considered for feasibility analyses of floating PV power plant projects.

- Prior to projecting floating PV power plants at any location, temperature and solar radiation data, maximum wind speed, snow load, water current, cyclone, and typhoon risks need to be analyzed.

- Anchoring cables require periodic inspection and maintenance in floating PV power plants.

Author Contributions: Conceptualization, E.C. and P.M.C.; methodology, E.C. and P.M.C.; data curation, E.C.; writing-original draft preparation, E.C., S.S. and A.G.; writing-review and editing, E.C., P.M.C., Y.S. and S.S.; visualization, Y.S.; supervision, E.C.; project administration, E.C. All authors have read and agreed to the published version of the manuscript.

Funding: This research received no external funding.

Institutional Review Board Statement: Not applicable. 
Informed Consent Statement: Not applicable.

Data Availability Statement: Not applicable.

Conflicts of Interest: The authors declare no conflict of interest.

\section{References}

1. IEA. Renewables Information 2019-International Energy Agency. IEA Static Reports 2019. Available online: https://www.iea. org/reports/renewables-information-2019 (accessed on 10 April 2020).

2. IEA. Data and Statistics-International Energy Agency 2020. Explore Energy Data by Category, Indicator, Country or Region. Available online: https:/ /www.iea.org/ (accessed on 10 April 2020).

3. Rosa-Clot, M.; Tina, G.M. Introduction. In PV Float. Plants, 1st ed.; Rosa-Clot, M., Tina, G.M., Eds.; Elsevier: Amsterdam, The Netherlands; Academic Press: Cambridge, MA, USA, 2020.

4. Sahu, A.; Yadav, N.; Sudhakar, K. Floating photovoltaic power plant: A review. Renew. Sustain. Energy Rev. 2016, 66, 815-824. [CrossRef]

5. Cuce, E.; Cuce, P.M.; Young, C.H. Energy saving potential of heat insulation solar glass: Key results from laboratory and in-situ testing. Energy 2016, 97, 369-380. [CrossRef]

6. Cuce, E.; Cuce, P.M. Tilt angle optimization of building-integrated photovoltaics (BIPVs) for cooler operating temperatures. In Proceedings of the MEGS IV Annual Conference, Public Engagement with Energy, Loughborough, UK, 12-13 September 2013.

7. Cuce, P.M.; Cuce, E. Passive cooling of building-integrated photovoltaics (BIPVs) for better electrical performance. In Proceedings of the MEGS IV Annual Conference, Public Engagement with Energy, Loughborough, UK, 12-13 September 2013.

8. Riffat, S.B.; Cuce, E. A review on performance analysis of photovoltaic/thermal collectors. In Proceedings of the Tenth International Conference on Sustainable Energy Technologies, Istanbul, Turkey, 4-7 September 2011.

9. Cuce, E.; Bali, T. Improving performance parameters of silicon solar cells using air cooling. In Proceedings of the Fifth International Ege Energy Symposium and Exhibition, Denizli, Turkey, 27-30 June 2010.

10. Cuce, E.; Cuce, P.M. Optimised performance of a thermally resistive PV glazing technology: An experimental validation. Eng. Rep. 2019, 5, 1185-1195. [CrossRef]

11. Kougias, I.; Bódis, K.; Jäger-Waldau, A.; Moner-Girona, M.; Monforti-Ferrario, F.; Ossenbrink, H.; Szabó, S. The potential of water infrastructure to accommodate solar PV systems in Mediterranean islands. Sol. Energy 2016, 136, 174-182. [CrossRef]

12. Trapani, K.; Millar, D.L.; Smith, H.C. Novel offshore application of photovoltaics in comparison to conventional marine renewable energy technologies. Renew. Eng. 2013, 50, 879-888. [CrossRef]

13. Energy Sector Management Assistance Program (ESMAP). Where Sun Meets Water-Floating Solar Market Report. Available online: http:/ / www.seris.nus.edu.sg/doc/publications/ESMAP (accessed on 27 April 2020).

14. Choi, Y.K. A study on power generation analysis of floating PV system considering environmental impact. Int. J. Softw. Eng. Its Appl. 2014, 8, 75-84. [CrossRef]

15. Liu, H.; Kumar, A.; Reindl, T. The Dawn of Floating Solar-Technology, Benefits, and Challenges. In WCFS2019; Springer: Singapore, 2020; pp. 373-383.

16. Martins, B.P. Techno-Economic Evaluation of a Floating PV System for a Wastewater Treatment Facility. Master's Thesis, KTH, School of Industrial Engineering and Management (ITM), Stockholm, Sweden, 2019.

17. World Bank Group. Where Sun Meets Water: Floating Solar Handbook for Practitioners. 2019. Available online: https: / / openknowledge.worldbank.org/handle/10986/32804 (accessed on 27 April 2020).

18. Duzenli, M.; Kocar, G.; Eryasar, A. A review of floating solar power plants. In Proceedings of the Solar Conference \& Exhibition, Istanbul, Turkey, 29-30 November 2018.

19. Friel, D.; Whittaker, M.; Doran, T.; Howlin, W.J. A review of floating photovoltaic design concepts and installed variations. In Proceedings of the Fourth International Conference on Offshore Renewable Energy, Glasgow, UK, 29-30 August 2019.

20. Ciel and Terre. Taking to the Waves: Gearing Floating PV towards Giant Projects! Available online: https://www.ciel-et-terre.net (accessed on 27 April 2020).

21. Cuce, E. Thermodynamic Analysis of the Effectiveness of Different Types of PV Modules for Wet Conditions. Master's Thesis, Karadeniz Technical University, Trabzon, Turkey, 2009.

22. Cuce, E.; Bali, T. Variation of cell parameters of a p-Si PV cell with different solar irradiances and cell temperatures in humid climates. In Proceedings of the Fourth International Exergy, Energy and Environment Symposium, Sharjah, United Arab Emirates, 19-23 April 2009.

23. Cuce, E.; Cuce, P.M.; Bali, T. An experimental analysis of illumination intensity and temperature dependency of photovoltaic cell parameters. Appl. Eng. 2013, 111, 374-382. [CrossRef]

24. Nishioka, K.; Hatayama, T.; Uraoka, Y.; Fuyuki, T.; Hagihara, R.; Watanabe, M. Field-test analysis of PV system output characteristics focusing on module temperature. Sol. Energy Mater. Sol. Cells 2003, 75, 665-671. [CrossRef]

25. Garcia, M.C.A.; Balenzategui, J.L. Estimation of photovoltaic module yearly temperature and performance based on nominal operation cell temperature calculations. Renew. Energy 2004, 29, 1997-2010. [CrossRef]

26. Teo, H.G.; Lee, P.S.; Hawlader, M.N.A. An active cooling system for photovoltaic modules. Appl. Eng. 2012, 90, 309-315. [CrossRef] 
27. Akbarzadeh, A.; Wadowski, T. Heat pipe-based cooling systems for photovoltaic cells under concentrated solar radiation. Appl. Therm. Eng. 1996, 16, 81-87. [CrossRef]

28. Tonui, J.K.; Tripanagnostopoulos, Y. Air-cooled PV/T solar collectors with low cost performance improvements. Sol. Eng. 2007, 81, 498-511. [CrossRef]

29. Cuce, E.; Bali, T.; Sekucoglu, S.A. Effects of passive cooling on performance of silicon photovoltaic cells. Int. J. Low-Carbon Technol. 2011, 6, 299-308. [CrossRef]

30. Agrawal, S.; Tiwari, G.N. Energy and exergy analysis of hybrid micro-channel photovoltaic thermal module. Sol. Energy 2011, 85, 356-370. [CrossRef]

31. Liu, H.; Krishna, V.; Lun Leung, J.; Reindl, T.; Zhao, L. Field experience and performance analysis of floating PV technologies in the tropics. Prog. Photovol. Res. Appl. 2018, 26, 957-967. [CrossRef]

32. Edalati, S.; Ameri, M.; Iranmanesh, M.; Tarmahi, H.; Gholampour, M. Technical and economic assessments of grid-connected photovoltaic power plants: Iran case study. Energy 2016, 114, 923-934. [CrossRef]

33. Liu, L.; Wang, Q.; Lin, H.; Li, H.; Sun, Q.; Wennersten, R. Power generation efficiency and prospects of floating photovoltaic systems. Eng. Procedia 2017, 105, 1136-1142. [CrossRef]

34. Redón Santafé, M.; Torregrosa Soler, J.B.; Sánchez Romero, F.J.; Ferrer Gisbert, P.S.; Ferrán Gozálvez, J.J.; Ferrer Gisbert, C.M. Theoretical and experimental analysis of a floating photovoltaic cover for water irrigation reservoirs. Energy 2014, 67, 246-255. [CrossRef]

35. Song, J.; Choi, Y. Analysis of the potential for use of floating photovoltaic systems on mine pit lakes: Case study at the Ssangyong open-pit limestone mine in Korea. Energies 2016, 9, 102. [CrossRef]

36. Kim, S.M.; Oh, M.; Park, H.D. Analysis and prioritization of the floating photovoltaic system potential for reservoirs in Korea. Appl. Sci. 2019, 9, 395. [CrossRef]

37. Mittal, D.; Kumar Saxena, B.; Rao, K.V.S. Potential of floating photovoltaic system for energy generation and reduction of water evaporation at four different lakes in Rajasthan. In Proceedings of the 2017 International Conference on Smart Technologies for Smart Nation (SmartTechCon), Bangalore, India, 17-19 August 2017; pp. 238-243.

38. Pasalic, S.; Aksamovic, A.; Avdakovic, S. Floating photovoltaic plants on artificial accumulations-Example of Jablanica Lake. In Proceedings of the 5th IEEE International Energy Conference, Limassol, Cyprus, 3-7 June 2018; pp. 1-6.

39. Water Supplies Development. Floating Solar Power System. Available online: https://www.wsd.gov.hk (accessed on 27 April 2020).

40. Farfan, J.; Breyer, C. Combining floating solar photovoltaic power plants and hydropower reservoirs: A virtual battery of great global potential. Eng. Procedia 2018, 155, 403-411. [CrossRef]

41. Santafé, M.R.; Ferrer Gisbert, P.S.; Sánchez Romero, F.J.; Torregrosa Soler, J.B.; Ferrán Gozálvez, J.J.; Ferrer Gisbert, C.M. Implementation of a photovoltaic floating cover for irrigation reservoirs. J. Clean. Prod. 2014, 66, 568-570. [CrossRef]

42. Rosa-Clot, M.; Tina, G.M.; Nizetic, S. Floating photovoltaic plants and wastewater basins: An Australian project. Eng. Procedia 2017, 134, 664-674. [CrossRef]

43. Mittal, D.; Saxena, B.K.; Rao, K.V.S. Floating solar photovoltaic systems: An overview and their feasibility at Kota in Rajasthan. In Proceedings of the IEEE International Conference on Circuit, Power and Computing Technologies, Kollam, India, 20-21 April 2017.

44. Mittal, D.; Saxena, B.K.; Rao, K.V.S. Comparison of floating photovoltaic plant with solar photovoltaic plant for energy generation at Jodhpur in India. In Proceedings of the 2017 International Conference on Technological Advancements in Power and Energy (TAP Energy), Kollam, India, 21-23 December 2017.

45. Bist, R.R.; Saaqib, M. Comparison between floating solar PV plant and grounded PV plant at Bhimtal. Int. J. Res. Eng. Sci. Manag. 2019, 2, 453-456.

46. Rosa-Clot, M.; Tina, G.M. Integration of PV floating with hydroelectric power plants (HPPs). In Floating PV Plants, 1 st ed.; Rosa-Clot, M., Tina, G.M., Eds.; Elsevier: Amsterdam, The Netherlands; Academic Press: Cambridge, MA, USA, 2020 ; p. 129.

47. Cazzaniga, R.; Rosa-Clot, M.; Rosa-Clot, P.; Tina, G.M. Integration of PV floating with hydroelectric power plants. Heliyon 2019, 5 e01918. [CrossRef]

48. Power Technology. Sunshine on the Water: Floating Solar Arrays Gather Steam. Available online: https://www.powertechnology.com/features/featuresunshine-on-the-water-floating-solar-arrays-gather-steam-4912782 (accessed on 27 April 2020).

49. Ciel and Terre. Sayreville, New Jersey, Installed the Largest Hydrelio Floating Solar System in North America. Available online: https:/ / www.ciel-et-terre.net/ sayreville-new-jersey-installed-the-largest-hydrelio-floating-solar-system-in-north-america (accessed on 27 April 2020).

50. Ciel and Terre. HIKUNI IKE: 1308 kWp. Available online: https:/ /www.ciel-et-terre.net/project/hikuni-ike-1308-kwp/ (accessed on 10 May 2020).

51. Ciel and Terre. GOIAS FARM: 305 kWp. Available online: https://www.ciel-et-terre.net/project/goias-farm-305-kwp/ (accessed on 10 May 2020).

52. Loughran, J. Floating Solar Panels Are Being Tested as a Way to Power Operations at a Huge Mine in Chile and Reduce Water Loss at the Site. Available online: https:/ / eandt.theiet.org/content/articles/2019/03/floating-solar-panel-island-deployed-togreenify-mining-operations (accessed on 10 May 2020). 
53. Pouran, H.M. From collapsed coal mines to floating solar farms, why China's new power stations matter. Eng. Policy 2018, 123, 414-420. [CrossRef]

54. Ciel and Terre. LAS TÓRTOLAS: 85 kWp. Available online: https://www.ciel-et-terre.net/project/las-tortolas-85-kwp (accessed on 10 May 2020).

55. Choi, Y.K.; Lee, N.H.; Kim, K.J. Empirical Research on the Efficiency of Floating PV Systems Compared with Overland PV Systems. In Advances in Information Technology and Computer Science, CES-CUBE; American Scientific Publishers: New York, NY, USA, 2013; Volume 25, pp. 284-289.

56. Kim, S.H.; Yoon, S.J.; Choi, W.; Choi, K.B. Application of floating photovoltaic energy generation systems in South Korea. Sustainability 2016, 8, 1333. [CrossRef]

57. Lee, Y.G.; Joo, H.J.; Yoon, S.J. Design and installation of floating type photovoltaic energy generation system using FRP members. Solar Eng. 2014, 108, 13-27. [CrossRef]

58. Azmi, M.S.M.; Othman, M.Y.H.; Ruslan, M.H.H.; Sopian, K.; Majid, Z.A.A. Study on electrical power output of floating photovoltaic and conventional photovoltaic. Am. Inst. Phys. 2013, 1571, 95-101.

59. Majid, Z.; Ruslan, M.; Sopian, K.; Othman, M.; Azmi, M. Study on performance of 80 watt floating photovoltaic panel. J. Mech. Eng. Sci. 2014, 7, 1150-1156. [CrossRef]

60. Yadav, N.; Gupta, M.; Sudhakar, K. Energy assessment of floating photovoltaic system. In Proceedings of the 2016 International Conference on Electrical Power and Energy Systems (ICEPES), Bhopal, India, 14-16 December 2016; pp. 264-269.

61. Golroodbari, S.Z.; van Sark, W. Simulation of performance differences between offshore and land-based photovoltaic systems. Prog. Photovolt. Res. Appl. 2020, 28, 873-886. [CrossRef]

62. Kenning, T. World's Largest Floating Solar Plant Comes Partially Online in China. 2017. Available online: https://www.pv-tech org/news / worlds-largest-floating-solar-plant-comes-partially-online-in-china (accessed on 4 May 2020).

63. Hangzhou Hongcheng. Anhui Huainan 150 MW Surface Floating Photovoltaic Project Connected to the Grid. 2019. Available online: http:/ / www.hongchengtm.com/news/4.html (accessed on 4 May 2020).

64. Xin, Z. Massive Floating Power Plant up and Running. Available online: http:/ /www.chinadaily.com.cn/ (accessed on 3 May 2020).

65. DCTI. General Information I Sungrow Guqiao Floating Solar Plant. Available online: http:/ / www.dcti.de (accessed on 4 May 2020).

66. Trinasolar. Yingshang Mining Subsidence. Available online: https://www.trinasolar.com/en-glb/resources/success-stories/ Fuyangshi-yishanggucheng (accessed on 4 May 2020).

67. Sungrow. The Leader of Floating PV System. Available online: https://www.sungrowpower.com/sites/default/files/Leader-offloating-pv-systems.pdf (accessed on 4 May 2020).

68. Ciel and Terre. ANHUI CECEP: 70,005 kW. Available online: https://www.ciel-et-terre.net/project/anhui-cecep-70005-kwp (accessed on 4 May 2020).

69. Trinasolar. Huaibei Mining Subsidence. Available online: https://www.trinasolar.com/en-glb/resources/success-stories/Anhuihuaibei-caimeishenxianqu (accessed on 4 May 2020).

70. Ciel and Terre. ANHUI GCL: 32,686 kWp. Available online: https://www.ciel-et-terre.net/project/anhui-gcl-32686-kwp (accessed on 4 May 2020).

71. BayWa. Floating PV References Developed by BayWa r.e. Available online: https://www.baywa-re.de/en/floating-pv/floatingpv-references/\#bomhofsplas (accessed on 6 May 2020).

72. Korea JoongAng Daily. Floating Farms Offer Solar Power Solution. 2020. Available online: https://koreajoongangdaily.joins $\mathrm{com} /$ news/article/article.aspx?aid=3067165 (accessed on 4 May 2020).

73. Akua Energy. Omega 1. 2019. Available online: https://www.akuoenergy.com/en/omega-1 (accessed on 4 May 2020).

74. TMI Staff and Contributors. 13.7 MW Floating Solar Power Plant Starts Operating. Available online: https://www. turbomachinerymag.com/13-7mw-floating-solar-power-plant-starts-operating (accessed on 4 May 2020).

75. Ciel and Terre. AGONGDIAN: 9994 kWp. Available online: https://www.ciel-et-terre.net/project/agongdian-9994-kwp (accessed on 5 May 2020).

76. Ceil and Terre. PEI COUNTY: 9982 kWp. Available online: https://www.ciel-et-terre.net/project/pei-county-9982-kwp (accessed on 5 May 2020).

77. Ciel and Terre. UMENOKI: 7550 kWp. Available online: https://www.ciel-et-terre.net/project/umenoki-7550-kwp (accessed on 5 May 2020).

78. Ciel and Terre. GCL JINING: 6776 kWp. Available online: https:/ /www.ciel-et-terre.net/project/gcl-jining-6776-kwp (accessed on 5 May 2020).

79. Ceil and Terre. QUEEN ELIZABETH II: 6338 kWp. Available online: https:/ / www.ciel-et-terre.net/project/queen-elizabeth-ii-63-mwp (accessed on 5 May 2020).

80. Marray, M. Risen Energy to Provide Panels for Malaysian Floating Solar Mega Project. Available online: https://theasset.com/ belt-road-online/38994/risen-energy-to-provide-panels-for-malaysian-floating-solar-mega-project--news-1507-o (accessed on 5 May 2020).

81. Matich, B. Masdar to Install 145 MW of Floating PV in Indonesia. Available online: https://www.pv-magazine.com/2020/01/16 /masdar-to-build-145-mw-of-floating-pv-in-indonesia (accessed on 5 May 2020). 
82. Gupta, U. Indian Reservoirs Could Host 280 GW of Floating Solar. Available online: https://www.pv-magazine-india.com/2020 /02/ (accessed on 5 May 2020).

83. Bellini, E. South Korean Government Announces 2.1 GW Floating PV Project. Available online: https:/ / www.pv-magazine.com/ 2019/07/19/south-korean-government-announces-2-1-gw-floating-pv-project/ (accessed on 6 May 2020).

84. Pimentel Da Silva, G.D.; Branco, D.A.C. Is floating photovoltaic better than conventional photovoltaic? Assessing environmental impacts. Impact Assess. Proj. Apprais. 2018, 36, 390-400. [CrossRef]

85. Rosa-Clot, P. FPV and Environmental Compatibility. In Floating PV Plants; Elsevier: Amsterdam, The Netherlands, 2020; pp. 101-118.

86. Exley, G.; Armstrong, A.; Page, T.; Jones, I.D. Floating photovoltaics could mitigate climate change impacts on water body temperature and stratification. Solar Eng. 2021, 219, 24-33. [CrossRef]

87. Al-Widyan, M.; Khasawneh, M.; Abu-Dalo, M. Potential of floating photovoltaic technology and their effects on energy output, water quality and supply in Jordan. Energies 2021, 14, 8417. [CrossRef]

88. Kirke, B. Circulation, destratification, mixing and aeration: Why and how? Water 2000, 27, 24-30.

89. Rossum, J.R. Fundamentals of Metallic Corrosion in Fresh Water. Available online: https:/ / pdfs.semanticscholar.org/ (accessed on 7 May 2020).

90. Mathis, W. Europe's Largest Floating Solar Farm Underway in Netherlands. Available online: https:/ /www.bloomberg.com/ news/articles/2020-02-11/europe-s-largest-floating-solar-farm-underway-in-netherlands (accessed on 6 May 2020).

91. Enkhardt, S. German Coal Mines Could Host 3 GW of Floating PV. 2020. Available online: https://www.pv-magazine.com/2020 /02/03/german-coal-mines-could-host-3-gw-of-floating-pv (accessed on 6 May 2020).

92. Hacke, P. Overview of IEC Testing for PID. 2015. Available online: https://www.nrel.gov/pv/assets/pdfs/2015_pvmrw_113_ hacke.pdf (accessed on 6 May 2020).

93. Bellini, E. Casting Light on Backsheet Degradation. Available online: https://www.pv-magazine.com/2020/03/11/casting-lighton-backsheet-degradation/ (accessed on 6 May 2020).

94. Bellini, E. UK Researchers Confirm Correlation between Micro-Cracks and Hot Spots in Polycrystalline Cells. Available online: https: / / www.pv-magazine.com/2020/01/07/uk-researchers-confirm-correlation-between-micro-cracks-and-hot-spotsin-polycrystalline-cells / (accessed on 7 May 2020).

95. Demirtaş, M.; Tamyürek, B.; Kurt, E.; Çetinbaş, İ.; Öztürk, M.K. Effects of aging and environmental factors on performance of CdTe and CIS thin-film photovoltaic modules. J. Electron. Mater. 2019, 48, 6890-6900. [CrossRef] 